\title{
Vehicle access and falling transit ridership: evidence from Southern California
}

\author{
Michael Manville $^{1}$ (D) Brian D. Taylor $^{1}$ (D) Evelyn Blumenberg ${ }^{1}$ (D) \\ Andrew Schouten ${ }^{2}$ iD
}

Accepted: 16 November 2021 / Published online: 3 February 2022

(C) The Author(s), under exclusive licence to Springer Science+Business Media, LLC, part of Springer Nature 2022

\begin{abstract}
We examine pre-COVID declines in transit ridership, using Southern California as a case study. We first illustrate Southern California's unique position in the transit landscape: it is a large transit market that demographically resembles a small one. We then draw on administrative data, travel diaries, rider surveys, accessibility indices, and Census microdata for Southern California, and demonstrate a strong association between rising private vehicle access, particularly among the populations most likely to ride transit, and falling transit use. Because we cannot control quantitatively for the endogeneity between vehicle acquisition and transit use, our results are not causal. Nevertheless, the results strongly suggest that increasing private vehicle access helped depress transit ridership. Given Southern California's similarity to most US transit markets, we conclude that vehicle access may have played a role in transit losses across the US since 2000.
\end{abstract}

Keywords Mode choice $\cdot$ Public transit - Ridership

Michael Manville

mmanvill@ucla.edu

Brian D. Taylor

btaylor@ucla.edu

Evelyn Blumenberg

eblumenb@ucla.edu

Andrew Schouten

schouten@fc.ritsumei.ac.jp

1 Department of Urban Planning, Institute of Transportation Studies, and Lewis Center for Regional Policy Studies, University of California, Los Angeles, 3250 Public Affairs Building, Box 951656, Los Angeles, CA 90095-1656, USA

2 School of Policy Science, Ritsumeikan University, 2-150 Iwakura-cho, Ibaraki, Osaka 567-8570, Japan 


\section{Introduction}

This paper analyzes the steep decline in US transit ridership that began in the years before the coronavirus emergency. Both absolute and per capita transit patronage fell during the Great Recession. Ridership began growing as the economy recovered, but soon started to fall (American Public Transportation Association 2021a). In 2012, Atlanta and Detroit became the first large urbanized areas (UZAs) to report post-recession year-over-year absolute ridership declines. They were followed by Chicago, Los Angeles, Philadelphia, and Washington, DC in 2014; Miami, Dallas, and Phoenix in 2015; and Boston in 2016. Transit ridership in many smaller regions began falling thereafter. In 2017, ridership rose in three UZAs, and fell in 436. Transit ridership losses continued in 2018 (U.S. Federal Transit Administration 2020). Nationwide, per capita transit patronage fell by $12 \%$ between 2008 and 2018; from 2014 to 2018, absolute ridership fell by 700 million (American Public Transportation Association 2021a; Schouten et al 2021).

These declines generated substantial concern while they were happening (e.g., Badger and Bui 2020), but they were soon eclipsed by the even graver problems that befell transit as a result of COVID-19 (Frost 2020; American Public Transportation Association 2021b). While the pandemic decimated transit use, the source of that decimation is no mystery. The economy contracted, and transit travel did too. The source of the pre-COVID decline, in contrast, is less clear, and is worth investigating because the conditions that created it may well remain, and confront transit agencies as they emerge from the pandemic.

Given the nature of American transit, the pre-COVID ridership decline likely had multiple causes. Transit in the United States serves different purposes, and takes different forms, in different places. Conditions that likely affected ridership in New York, Boston, and Washington, DC, such as service disruptions on aging rail systems, were less relevant or nonexistent elsewhere.

This article focuses on an explanation with relevance to many places: increased access to private automobiles. In most of the US, public transportation is used disproportionately by people who have limited access to cars, but who live and work in built environments designed for car travel. Transit, for this group, is a mobility safety net: a public option for moving through landscapes planned around private vehicles. Precisely because transit in these areas is often mismatched to its built environment, the service it offers is generally inferior to driving. This makes transit ridership precarious. The relatively small share of people with little or no vehicle access accounts for a large share of transit trips, but those same people without vehicles have a strong incentive to acquire them, because vehicles greatly improve their ability to get around. In these circumstances, even modest increases in vehicle access could account for large losses in transit ridership. We hypothesize that in many US areas, this is in fact what occurred.

We document the association between rising auto access and falling transit use by examining Southern California, and particularly the Los Angeles urbanized area (UZA) that lies at its heart. We emphasize Southern California because it offers an unusual window into America's transit landscape: a large transit market with many attributes of a small one. American transit use follows a power law distribution: a small number of big places, most of them quite different from the nation at large, account for most transit trips. Over $40 \%$ of the nation's pre-pandemic transit rides, for example, occurred in New York, a place that in many ways bears little resemblance to other US urban areas (e.g. Voulgaris et al. 2017). As a result, no single place offers an ideal case study of "American" transit. 
Nevertheless, Southern California makes a useful case study, for three reasons. The first is data limitations. Fully controlling for endogeneity in a national analysis of vehicle ownership and transit use is difficult, because data on a number of potentially confounding factors are either unavailable, or available only in data sets that are hard to match with one another. Using a single large case, as offered by Southern California, helps overcome this problem: we can scrutinize potential sources of endogeneity separately from our statistical analysis, in ways that would be difficult if we analyzed numerous areas.

Second, using Southern California rules out an important potential reason for falling ridership, which is falling investment. Southern California exemplifies, and indeed lies at the extreme end of, a national trend where transit investment has risen but ridership has lagged. From 2000 to 2015, transit investment in the United States, measured as an inflation-adjusted ten-year rolling average of capital costs plus annual operating costs, rose almost 50\% (US Federal Transit Administration various), while per capita ridership fell 1\% (American Public Transportation Association 2021a). In Southern California, this divergence between investment and patronage is even starker. Since 1990, Southern California has added over 100 miles of light and heavy rail, over 530 miles of commuter rail, and increased bus service as well. Transit ridership over this period, however, has been mostly flat or falling; both absolute and per capita ridership had their postwar peak in 1985. The most recent per capita decline began in 2007, and ridership started falling absolutely in 2014. The decline was more pronounced on bus than rail, but both modes lost patronage. In 2016 per capita ridership was $40 \%$ below its 1985 high-water mark. ${ }^{1}$

Finally, we examine Southern California because the region is, again, a large transit market with many attributes of a small one. Today Los Angeles ranks third behind New York and Chicago in the number of annual transit trips; as recently as 2016, LA was second to only New York (Freemark 2021). But the region differs dramatically from America's other big transit markets. These other regions - the "legacy" urbanized areas concentrated in the Northeast (but including Chicago and San Francisco) — have central areas with dense prewar built environments, and these environments, by making driving and parking difficult, encourage broad swathes of the population to take transit (Chatman 2003; Taylor et al. 2009). Los Angeles, in contrast, more closely resembles the typical US urban area: much of its built environment is auto-oriented, and transit use is confined largely to the poor. Analyzing LA might therefore offer a better glimpse into why ridership fell in most places, even if it is less applicable to those places where frequent transit use is most common.

We proceed as follows. The next section discusses falling transit ridership, situates Los Angeles in America's transit landscape, and summarizes previous research on the relationship between vehicle access and transit use. The "Descriptive evidence on transit use and private vehicle access in Southern California" section presents descriptive evidence about rising auto access and falling transit ridership in Southern California.

The "Statistical analysis of vehicle access and falling ridership" section presents a series of negative binomial regressions measuring the relationship between private vehicle access and transit use. The results confirm a strong negative association: a decline in zero-vehicle households is strongly associated with substantially fewer transit trips, even controlling for income, age, race, nativity, and other factors. We stop short of defining this association causally, however. Rising auto access could cause falling ridership, but could also be a consequence of other underlying reasons to prefer driving over transit. Because we cannot

1 See Manville (2019) for data on investment and ridership. 
quantitatively control for this potential endogeneity, the "Endogeneity: changes in vehicle access vs changes that prompt vehicle access" section reviews other potential sources of transit's decline, and weighs them relative to rising vehicle access.

We conclude that increased vehicle access has likely played a central role in transit's pre-COVID decline. The article's final section considers the implications of this finding. Our results suggest a tension between the collective benefits that transit offers low-income people as a group, and the private benefits that automobiles offer to individual members of that same group. In many US urban areas, transit primarily relies for riders on people who lack cars (Pucher and Renne 2003). When vehicles become more widely available, that group shrinks. So too does transit's base of frequent users, and thus its ridership. A logical policy response, from the perspective of transit operators, is to lure these riders back. From a broader perspective, however, the appropriate response is less obvious. Because transit's collective benefits for low-income people rest on transit being viable, when riders of any income acquire vehicles and leave, an important service for low-income people suffers. At the same time, however, when low-income people living in auto-oriented places acquire automobiles, they likely become individually better off, because they can now travel by car in regions designed for doing so. The socially optimal response to falling ridership, therefore, likely involves more than just "winning back" riders who have left. Instead it would involve addressing the policies that create structural advantages for automobility.

Before proceeding, a note about geography; throughout the article we alternatively discuss "Los Angeles" by which we mean the Los Angeles Urbanized Area (UZA) or-sometimes-Los Angeles County, and "Southern California" which is a larger area including not just Los Angeles but five outlying counties that are represented by the metropolitan planning organization. Most ridership occurs in Los Angeles, as we discuss, but Southern California is the geographic scale at which regional transportation planning occurs.

\section{Auto use and transit ridership: considerations and causes}

The pattern of American transit use is one of nesting asymmetries. Ridership is concentrated in a small number of regions, and within those regions in a small number of places (usually the dense parts of center cities). Within these places, a small share of operators carries a disproportionate share of trips, often on a small number of heavily-traveled routes. The passengers themselves, meanwhile, are drawn from a small share of the population.

This small share of the population, moreover, is drawn from both the low-income and the affluent. Transit riders are significantly more likely than the general population to be poor, but not much less likely than the general population to be rich. In 2016, just over $20 \%$ of riders came from households with incomes under $\$ 15,000$, which is almost twice the share of US households that have incomes below that threshold. Just over $20 \%$ of transit riders, meanwhile, came from households with incomes over $\$ 100,000 ; 26 \%$ of US households overall fall in this group (Clark 2017; US Census 2016). A common thread uniting these otherwise dissimilar individuals is limited access to automobiles. Better than three out of five US transit riders (61\%) report not having a private vehicle available for their transit trip (Clark 2017).

Aggregate data, then, suggest that transit is a mode for both the low-income and the affluent, with a shared attribute of low vehicle access. These aggregate data conceal, however, the fact that transit's affluent users are concentrated in a small number of urban areas. This fact, in turn, complicates national statistics about transit use and vehicle access. Most 
transit riders have limited vehicle access, but limited vehicle access can arise for two reasons: because vehicle use is itself expensive (an attribute of a place), or because incomes are low (an attribute of people). In places where owning and operating a vehicle is costlyin money, time, or stress - transit has relative advantages, and even affluent people will use it. But these circumstances exist in only a handful of places: dense central cities with narrow streets, heavy congestion, and scarce parking. That description fits the nation's traditional transit centers - the "legacy" regions of New York, Chicago, San Francisco, Philadelphia, Boston, and Washington DC. These places developed around transit and retain, in their central areas, built environments that make riding transit easier and driving harder. As a result, they carry the vast majority of American transit trips, and transit in them delivers large environmental and efficiency benefits. In 2015 the legacy regions, which hold about $20 \%$ of the US urbanized population and cover about $11 \%$ of its urban land, hosted almost $65 \%$ of its transit trips. The 433 other UZAs, meanwhile, hold $80 \%$ of the urban population but carry only $35 \%$ of all transit trips. ${ }^{2}$

In these latter UZAs - most UZAs - driving is relatively cheap, and lower access to private vehicles usually reflects low income, and to a lesser extent medical or legal constraints that limit driving. In these places, where the landscape is arranged for cars and riding transit is much less convenient than driving, transit is best characterized as a social servicea mobility safety net used primarily by the poor (Glaeser et al. 2008; Taylor and Morris 2015).

At the risk of oversimplification, then, America has two transit regimes: the legacy regions, where the built environment can make driving difficult, and the rest of the country, where it does not. The latter regime includes most areas and most systems; the legacy regime carries most riders.

The stark difference between the legacy regions and the rest of the country complicates any discussion of "national" trends in transit ridership. If ridership falls $10 \%$ in the legacy regions and rises $20 \%$ everywhere else, US ridership would fall, even though transit would be making unprecedented ridership gains in hundreds of areas. Conversely, if legacy ridership surges, national ridership can grow, even if patronage falls in most of the country.

We illustrate this difference, and show LA's utility as a case study, by comparing Los Angeles transit riders to both the large LA population, and to US transit riders overall in Table 1. Data on LA ridership come from onboard surveys by LA Metro (Southern California's largest transit operator, which carries $70 \%$ of the region's trips, and almost $80 \%$ of the UZA's trips). Data on LA County's population come from the US Census, and data on US transit riders come from the American Public Transportation Association (Clark 2017). We present these latter data for the entire country, but also broken down by urban area size: areas of less than 200,000 people and of over 1 million people (the category dominated by the legacy regions and Los Angeles).

LA Metro riders are almost four times as likely as LA County residents to come from households with incomes under $\$ 15,000$ per year (44-12\%) and only one-third as likely to come from households with incomes over $\$ 100,000$ (11-30\%). Only $11 \%$ of Metro riders are white, compared to $27 \%$ of county residents. Most notably, $78 \%$ of Metro riders report not having a vehicle for their transit trip, while only $11 \%$ of county residents

\footnotetext{
${ }^{2}$ Calculated from National Transit Database's 2016 UZA Allocation Tables. The legacy regions account for an even smaller share of overall US population and land area: $11 \%$ of population and less than $1 \%$ of land.
} 
Table 1 Characteristics of LA Metro Riders, LA County Residents, and US Transit Riders Overall, 2016. Sources: LA Metro Rider Surveys, US Census (2016) and Clark (2017)

\begin{tabular}{lllll} 
LA County & LA Metro & \multicolumn{3}{l}{ US transit riders } \\
\cline { 3 - 5 } Residents (\%) & Riders (\%) & $\begin{array}{l}\text { Areas <200k } \\
(\%)\end{array}$ & $\begin{array}{l}\text { Areas }>1 \\
\text { million (\%) }\end{array}$ & All (\%) \\
\hline 27 & 11 & 50 & 40 & 40 \\
12 & 44 & 48 & 20 & 21 \\
30 & 11 & 6 & 22 & 21 \\
11 & 78 & 75 & 46 & 61 \\
& & 35 & 59 & 44 \\
& & 46 & 14 & 30
\end{tabular}

Vehicle availability comparisons are imperfect. Metro asks if the rider had a vehicle available for the current trip, while the Census asks if the household had a vehicle available in general. Riders are classified as "preferring transit" if they say it is more convenient, saves time, or that they ride for environmental reasons. Riders who report riding because they lack an automobile, or who say transit is the only transportation they have, are categorized as riding because they have no car

live in a household without vehicles. Transit in Los Angeles is used disproportionately by low-income people with limited car access.

The four columns of the table that compare LA Metro riders to transit riders nationally paint a startling picture: riders on LA Metro, one of the nation's largest transit operators, most closely resemble riders in the nation's smallest urban areas. On measures of income and especially vehicle access, Metro riders look more like riders in Topeka or Waco, than like riders in Chicago or Philadelphia—despite LA being included in, and thus influencing, the large urban area calculations. Compared to riders in large urban areas overall, LA Metro riders are more than twice as likely to have incomes of less than $\$ 15,000$ per year, and half as likely to have incomes of over $\$ 100,000$ per year. Fully $78 \%$ of LA Metro riders report lacking access to a vehicle, comparable to $75 \%$ of riders who report the same in the smallest areas, and well above the $46 \%$ in the largest. The table's final rows show that transit riders in large areas are far more likely to report riding transit because they prefer it (59\% compared to $35 \%$ in small areas), while passengers in the smallest areas are more likely to report riding because they do not have a car (46\% compared to $14 \%)$.

Table 2, which uses data from the University of Minnesota's Accessibility Observatory, shows the stark advantage vehicle access confers in Los Angeles, relative to the legacy regions. The table shows the average number of jobs that can be reached in 30 minutes by automobile and transit in both 2014 and 2017. (This figure is calculated as the number of jobs reachable from an "average" point in the region; for example, the accessibility measure for New York will include both the high auto access of its suburbs and the low auto access and high transit access of Manhattan. For 2017, we also show this figure for the 50 largest MSAs combined.)

In all these regions cars offer more access than transit. At the same time, automobile access has fallen dramatically over time in every region, mostly due to worsening congestion. Transit access, in contrast, has risen in some regions and fallen in others.

Most important for our purposes, however, is that transit riders in the legacy regions surrender far less employment accessibility to drivers than do riders in Los Angeles. In New York, which is admittedly an outlier, the automobile in 2014 offered 10 times more 
Table 2 Accessibility by auto and transit: Jobs reachable in $30 \mathrm{~min}$ by mode. Sources: Owen and Murphy (2018a, 2018b), Owen and Levinson (2014), Owen et al. (2016) and Levinson (2013)

\begin{tabular}{|c|c|c|c|c|c|c|}
\hline & \multicolumn{3}{|l|}{2014} & \multicolumn{3}{|l|}{2017} \\
\hline & Auto & Transit & Ratio & Auto & Transit & Ratio \\
\hline Los Angeles & $2,390,608$ & 43,430 & 55.0 & $1,282,378$ & 38,647 & 33.2 \\
\hline Boston & $1,015,035$ & 49,237 & 20.6 & 605,308 & 44,014 & 13.8 \\
\hline Chicago & $1,235,879$ & 48,116 & 25.7 & 769,483 & 53,801 & 14.3 \\
\hline New York & $2,084,022$ & 210,186 & 9.9 & $1,241,973$ & 213,407 & 5.8 \\
\hline Philadelphia & 922,000 & 35,217 & 26.2 & 618,294 & 38,185 & 16.2 \\
\hline San Francisco & $1,451,337$ & 65,246 & 22.2 & 652,817 & 81,285 & 8.0 \\
\hline Washington DC & $1,159,070$ & 47,759 & 24.3 & 623,387 & 50,551 & 12.3 \\
\hline & & & & 50 MSA average & & 54.7 \\
\hline
\end{tabular}

Auto 2014 is an average of 2013 and 2015 calculations. Results are not substantially different if the 2013 or 2015 reports are used alone

employment access than transit did. By 2017 this ratio had fallen to 6-to- 1 . The other legacy regions, while nowhere near New York, exhibit the same trend: the ratio of auto to transit accessibility ranged between 20:1 and 26:1 in 2014, and between 8:1 and 14:1 in 2017. In every legacy region but Boston, moreover, the auto-transit gap shrunk. This reduction occurred not just because the number of jobs reachable by auto fell, but also because the number of jobs reachable by transit grew.

In Los Angeles, in contrast, job access via automobile in 2014 was 55 times higher than job access by transit. By 2017 this auto-transit ratio had fallen to 33:1—smaller, but still more than double the ratio in the nearest legacy region. The smaller ratio in LA, moreover, was entirely the result of falling automobile access, since transit access fell as well, albeit not by as much. Worsening congestion contributed to both declines.

Note that transit access to jobs in Los Angeles is high in absolute terms, comparable to Boston and Philadelphia. What makes Los Angeles different is the relative advantage of the automobile. Philadelphia's transit access is essentially equal to LA's, but it has only half LA's auto access to jobs, a testament to both the many parts of Philadelphia that are old and dense, and to the extent of LA's auto-orientation.

In sum: as a transit market, Southern California rivals the legacy regions in size, but more closely resembles much smaller regions in its rider characteristics. This fact, combined with the large relative advantages of the automobile in reaching jobs, suggests that many Southern California transit riders, if they had access to vehicles, might drive rather than ride. This supposition, in turn, aligns with the existing research literature documenting the barriers and burdens confronting people who live in auto-oriented environments but lack automobiles (King et al. 2019), and the value that such people place on acquiring cars (Aaronson et al. 2012; Adams et al. 2009; Blumenberg and Pierce 2012; Leininger et al. 2010; Parker et al. 2013). Taken together, these facts suggest that rising vehicle access could contribute to falling ridership in Los Angeles. 


\section{Descriptive evidence on transit use and private vehicle access in Southern California}

We analyze the period from roughly 2000 to 2016, a time frame that includes the years prior to the ridership decline, as well as nearly ten years of decline itself. Per capita transit ridership began falling in Southern California in 2007, from about 42 trips in that year to 35 trips in 2016. Absolute ridership losses began after 2013; between 2013 and 2016, the region's buses accounted for $84 \%$ of ridership losses, while rail accounted for $12 \%$.

The same asymmetries that define transit use nationwide are also evident in Southern California. A small share of people takes a large share of trips, and a large share of trips are carried by a small share of operators. The six-county Southern California region is over 38,000 square miles and has over 100 transit operators. But just 11 of those operators provide $60 \%$ of the service and carry about $80 \%$ of the trips. Census data show that $10 \%$ of all of the region's transit commuters in 2015 lived on just one-fifth of $1 \%$ of the region's land area; the mean number of transit commuters in these few tracts was almost 12 times the regional average. The region's largest operator, LA Metro, which serves Los Angeles County, carries over $70 \%$ of the region's trips, many of them on its 20 busiest routes (Manville et al. 2018). ${ }^{3}$

Data from the 2012 California Household Travel Survey (CHTS) show that in both LA County and Southern California overall, 2-3\% of the population rides transit frequently (averaging 45 trips/month) and accounts for almost 30\% of all transit trips. ${ }^{4}$ Another $20 \%$ ride transit occasionally (averaging 12 trips/month), and accounts for over half of all transit trips. Finally, almost $77 \%$ of residents ride transit little or not at all (averaging less than one trip/month). This very large group of infrequent riders accounts for about $17 \%$ of all transit trips. About $85 \%$ of transit rides, then, are taken by less than a quarter of the population. ${ }^{5}$

Would rising vehicle access undermine this ridership? Auto access can increase in different ways. Most obviously, it increases when households without vehicles get them, or when households with fewer vehicles than adults add an automobile. But access also can increase when rides in other people's cars become easier to get. This can occur if family, friends, or acquaintances acquire automobiles, or if automobile rides become more available a la carte - as they did in the early 2010s when ridehail services expanded. For reasons of data availability, our analysis emphasizes rising access to private vehicles, though we return later to the question of ridehailing.

Figure 1, drawn from the CHTS, shows that Southern California's frequent transit riders are disproportionately poor, nonwhite, foreign born, and carless. The figure's dashed vertical line represents the region's daily mean of unlinked transit trips. The location of the circle associated with each subgroup shows that subgroup's average daily transit ridership, while the size of that circle shows the relative size of each subgroup's population. African-Americans and Hispanics ride transit about three times as much as whites and Asians.

\footnotetext{
${ }^{3}$ LA Metro ridership is sufficiently concentrated that from 2011 to 2016 losses along a dozen of its routes accounted for $38 \%$ of all the lost ridership in California.

4 Administered by the California Department of Transportation, the 2012 CHTS is a one-day survey stratified to represent households in all California counties, including Los Angeles. The sample provides detailed demographic and travel behavior characteristics for over 42,500 households.

5 LA Metro boarding data from 2017 suggest the same pattern holds in LA County: over a four-month period, $7 \%$ of County residents accounted for $14 \%$ of farecards in circulation, but $77 \%$ of boardings (Vinayak et al. 2019).
} 

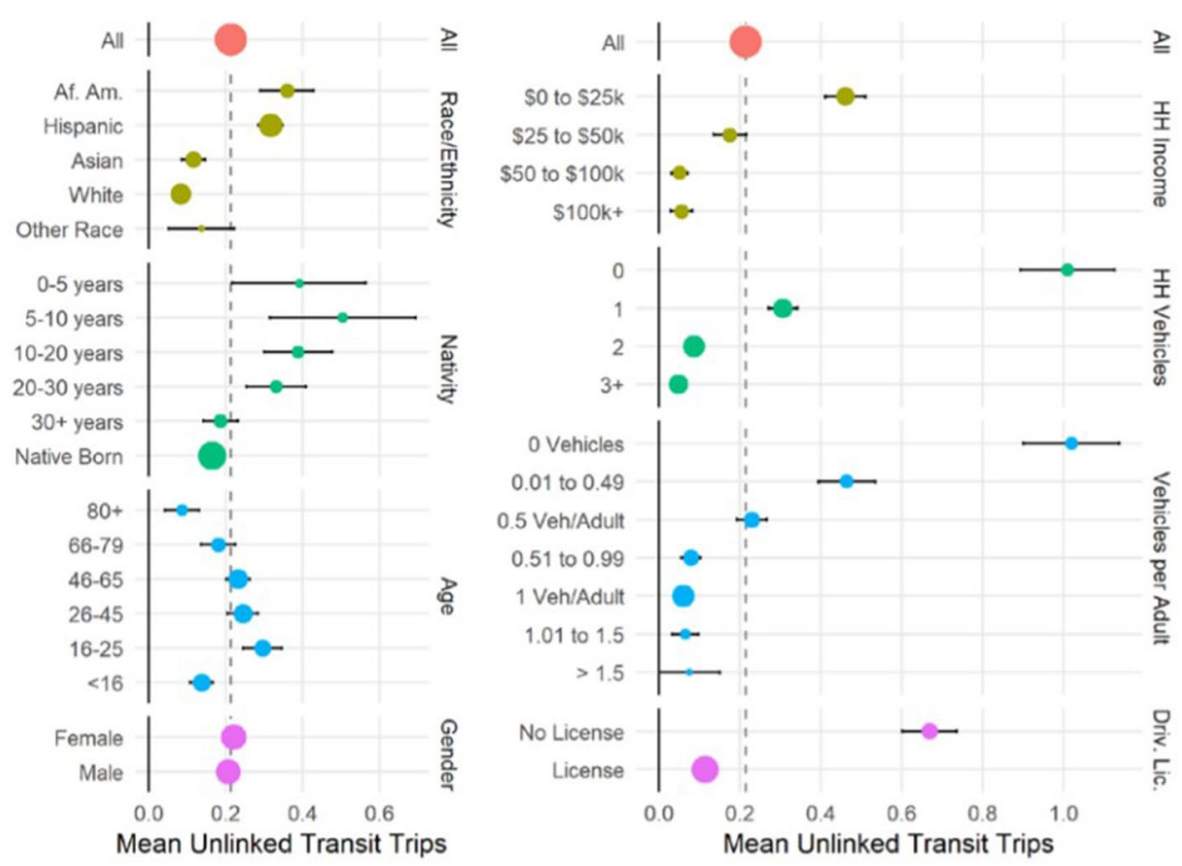

Fig. 1 Southern California transit use levels by socio-economic and auto access characteristics. Notes The size of each circle indicates the relative share of transit users in that category, while the horizontal bars indicate the 95\% confidence interval for each category. Source: California Department of Transportation (2012)

Immigrants ride more than the native-born, and recent immigrants ride more than immigrants residing in the US longer. ${ }^{6}$ Households earning under $\$ 25,000$ per year ride over twice as much as households earning $\$ 25,000$ to $\$ 50,000$, who in turn ride twice as much as households earning over $\$ 50,000$ annually.

The strongest correlations with transit use are found in the vehicle access variables: number of household vehicles, vehicles per adult, and drivers' licenses. The circles are small because low vehicle access and lack of licensure are uncommon. The circles lie far from the mean because people in households without vehicles used transit almost five times as much as people in households with one vehicle, and people in households with one vehicle take twice as many trips as those in households with two. Similarly, people in households with one vehicle for every two adults take twice as many trips as people in households with one vehicle per adult. People without driver's licenses took six times as many transit trips as people with a license.

Private vehicle ownership rose in Southern California as transit patronage fell. Census summary file data show that from 1990 to 2000, the region added 1.8 million people and 456,000 household vehicles (or 0.25 vehicles per new resident). From 2000 to 2015, however, Southern California added 2.3 million people and 2.1 million household vehicles (or 0.95 vehicles per new resident)_a rate almost four times that of the $1990 \mathrm{~s}$.

\footnotetext{
${ }^{6}$ Although not shown in the figure, other research suggests that transit use is more common among immigrants from Mexico and Latin America compared to immigrants from other countries of origin (Chatman 2014).
} 
Someone skeptical of vehicle ownership's role in falling transit ridership could rightfully point to two concerns. First, vehicles are expensive. Low-income people have trouble affording vehicles, and low-income people ride transit more. So perhaps vehicle access is just an artifact of income, and what really matters for transit ridership is a region's number of low-income households. Indeed, between 2000 and 2015, the share of households earning less than $\$ 25,000$ per year fell sharply, from about 30 to $23 \%$.

Second, many and probably most of the region's new vehicles did not directly reduce transit ridership. For the majority of households whose members almost never ride transit, an additional vehicle increases household car ownership (and perhaps driving) but does not depress household transit use.

In the next section we use regressions to control explicitly for these factors. But we can also address them briefly here with descriptive data. First, Fig. 1 showed that the absence of a vehicle or driver's license is a much stronger predictor of transit use than is low-income alone. Census data further show, moreover, that while the proportion of low-income households fell in LA County, the number of such households rose-from about 562,000 to just under 700,000 — and it is people, not proportions, who ride transit.

A third point is that Fig. 2, which plots the change in households with fewer vehicles than adults, shows that vehicle access increased across the socioeconomic spectrum, including in households more likely to ride transit. In 2000, just under $50 \%$ of nativeborn households earning less than $\$ 25,000$ per year had fewer vehicles than adults, as did almost $70 \%$ of immigrant households in the same income bracket. By 2015 these shares had fallen to $40 \%$ and $60 \%$, respectively. Thus in two groups that contribute substantially to transit use - the poor and the foreign-born-vehicle access rose.

These patterns are even more pronounced among households with zero vehicles. Census microdata (Ruggles et al. various) show that from 2000 to 2015, the share of zero-vehicle households in Southern California fell by $30 \%$. Among foreign-born residents, it fell $42 \%$, and among foreign-born households from Mexico, a group with traditionally high transitusage rates, it fell by $66 \%$.

\section{Statistical analysis of vehicle access and falling ridership}

In this section we estimate a series of negative binomial regressions to test the robustness of the correlation between vehicle access and transit use. Our statistical analysis confronts two primary obstacles, one conceptual and one empirical. The conceptual problem is

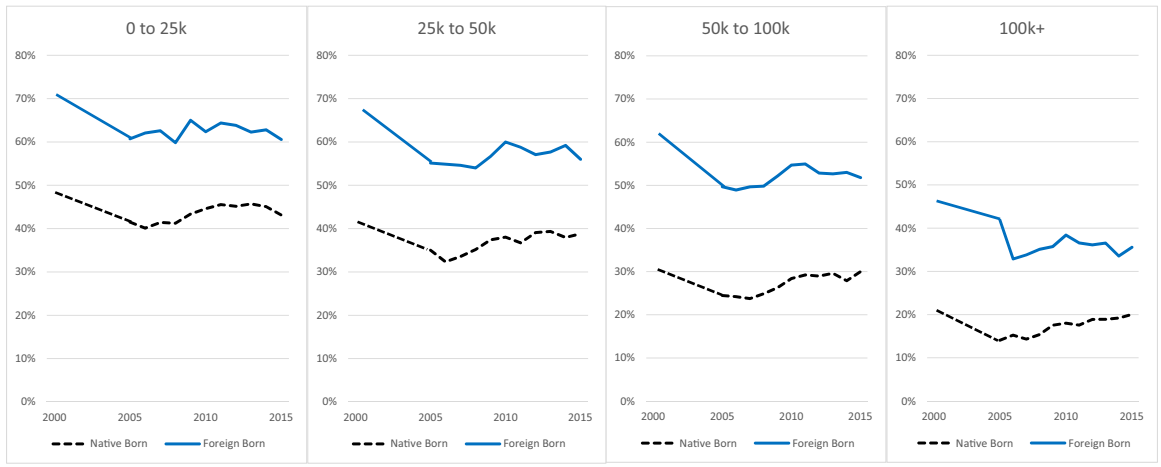

Fig. 2 Trends in the share of Southern California households with fewer vehicles than adults, by income and nativity, 2000-2015. Note: Solid line =foreign born, dashed line=native born. Source: US Census 
endogeneity; specifically, the difficulty of separating an underlying preference (how much to ride transit) from the means by which that preference is satisfied (the ability to access an automobile). People might ride transit less when they acquire automobiles, but automobiles are not randomly assigned to households. Most people who acquire cars do so because they want to drive. If we assume that people's desired quantity of travel is roughly constant, ${ }^{7}$ then transit riders who acquire automobiles may do so because they want to ride transit less. In these circumstances, auto access is less a cause of falling transit use and more a symptom of an underlying desire to ride transit less. Whatever caused that underlying desire, and not the increased auto access, would be the ultimate "cause" of falling ridership.

One can accept this limitation (we do) yet still see a potentially causal role for auto ownership. The intuition here is as follows. In regions where transit functions primarily as a social service, a sizeable share of riders may have an underlying discontent with it: they are aware that transit is slower and less reliable than driving, and/or that their ridership is a function or signal of their lower socioeconomic status. If their ability to acquire a car does not change (i.e., car prices do not fall and/or their incomes do not rise), and some aspect of transit service gets worse (transit becomes less reliable), the endogeneity problem looms large. People would acquire vehicles because their dissatisfaction with transit grew. Suppose, however, that many riders have long wanted to drive more and ride transit less, and that neither their desire for a car nor their dissatisfaction with transit appreciably changed. What changed instead was their ability to acquire an automobile. In this case, while it remains appropriate to call underlying discontent the cause of falling ridership, it becomes more defensible to also call rising auto access a trigger in its own right.

The extent to which one or the other of these scenarios holds-and it is possible that both hold to different degrees-determines the extent of the endogeneity. Unfortunately, we lack the data to measure underlying discontent, so we cannot control persuasively for endogeneity. This problem is a function of our empirical obstacle: no single data set allows us to fully test our hypothesis.

Ideally we would be able to follow households - both riders and non-riders-over time in a single market, and observe how their transit behavior changes not just as they acquire automobiles, but also as the quality and quantity of transit service changes, as driving conditions and costs change, and so on. The data that measure these phenomena, however, are spread across multiple sources, rarely longitudinal, and frequently incompatible. Annual data on transit service quantity and (to a lesser extent) quality are available through the National Transit Database (NTD), but these data offer no information on the vehicle access or personal attributes of transit riders. Detailed household- and person-level data are available annually from the U.S. Census, but the Census for the most part does not include travel data. It tracks the journey to work, but not, crucially, the total number of transit trips.

The CHTS does not include data on the quality or quantity of transit service, but does provide in-depth data on travel of all types by Californians, as well as extensive personand household-level socioeconomic information. Unfortunately, the CHTS is a one-year snapshot of 2012. We thus have one data set that has household-level demographic data for multiple years but no transit ridership or service data; one that has household-level demographic and ridership data, but for only one year (and without service data); and one that has annual service data with no household-level data at all.

7 This assumption is uncontroversial: travel is generally considered a derived demand. 
We resolve these problems as best we can by combining CHTS and Census data in a twostep approach. We first use the CHTS to estimate a regression that predicts total unlinked transit trips as a function of different demographic, socioeconomic, and neighborhood attributes-sex, nativity, income, age, vehicle ownership, and so on. Crucially, in this regression we only use covariates that are included in both the CHTS and Census. We then take the parameters from this regression and apply them to Census data from different years $(2000,2005,2010,2015)$. This approach allows us to see how predicted ridership will change with changes in these various socioeconomic characteristics. We use the CHTS, in short, to estimate the relationship between transit use and different social and economic characteristics, and then use the Census to track how those characteristics have changed. Combining these estimates yields a single estimate of how changes in those characteristics would change transit ridership.

This approach is imperfect. First, it assumes a relatively constant relationship between transit use and the socioeconomic and demographic attributes we measure. We assume, in other words, that changes in transit use from 2000 to 2015 are driven primarily by changes in the composition of the population, and not by changes in the propensity to use transit by different population subgroups. So our approach is more valid, for example, if ridership changes over time because (all else equal) there are more or fewer people in poverty, or more or fewer people with vehicles, and not because people with the same poverty level or same vehicle access become more or less likely to ride transit. The latter scenario is possible, and we cannot discount it, but we also cannot measure it [although see Schouten et al (2021) for an examination of population composition and transit use in California].

Second, while our first step involves making predictions, we are not building predictive models. We test a particular hypothesis about vehicle access and transit use, and we build a model that includes those variables and adequately controls for other factors. We are not seeking regression output that precisely matches observed transit ridership. A model of that sort would require NTD data, and as we discussed above, using those data precludes use of the person-based socioeconomic data required to test our hypothesis. As such, our regression yields an estimate of the relative magnitude of the importance of auto access, not a precise measure of how many trips each additional increment of auto access actually cost Southern California.

Third, since our regressions do not include controls for changes in service quality and quantity, they do not control for endogeneity. As a result, our results are not causal. In the next section we descriptively explore the extent of potential endogeneity.

We build models for the six-county Southern California region, for Los Angeles County, and for the Southern California region outside Los Angeles. The unit of analysis is the individual survey respondent, and the dependent variable is the survey respondent's daily unlinked transit trips. Transit trips are an over-dispersed count variable, so we use negative binomial regressions. ${ }^{8}$

Figure 3 shows results from the first stage of our analysis (full regression results are in the Appendix). They suggest, consistent with both expectations and the descriptive data in Fig. 1, a strong negative relationship between transit trips and automobile access, even controlling for other factors. Beyond automobile access, transit use is positively associated

\footnotetext{
8 Because most people do not ride transit, the dependent variable in these regressions has many zero values. We experimented with zero-inflated negative binomial regressions, but in most cases they did not converge. Our judgment is that such inflation would make little difference. Zero-inflation is most useful with Poisson models, since the zeroes create over-dispersion and Poisson regressions assume equi-dispersion. But the conventional negative binomial is designed to manage over-dispersion, so zero-inflating it offers a smaller improvement (Allison 2012).
} 


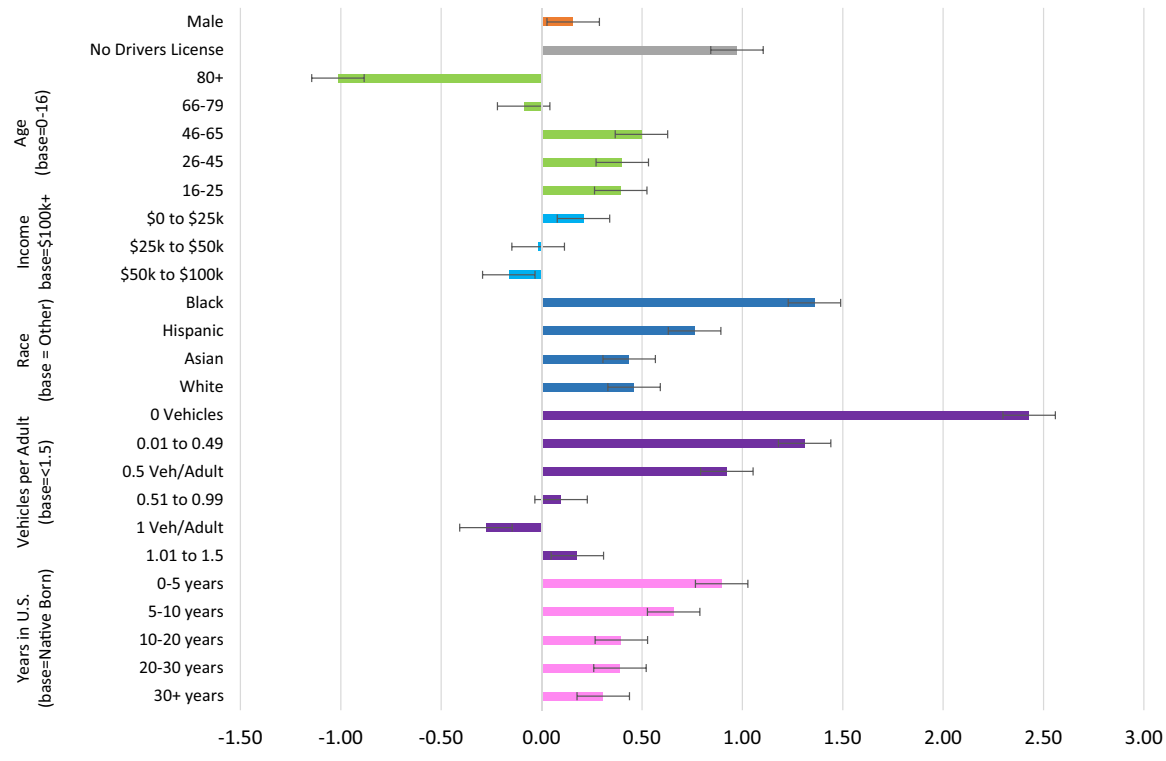

Fig. 3 Southern California unlinked transit trip predictors. Source: 2012 California Household Travel Survey

with the lack of a driver's license, being nonwhite, and being foreign-born-especially being foreign-born and recently-arrived. ${ }^{9}$

Figure 4 shows the results of applying these parameters to Integrated Public Use MicroSample (IPUMS) data from 2000, 2005, 2010, and 2015 (Ruggles et al. various years). To highlight the role of vehicle access, we present two models for each geographic area we analyze. The first model, represented by the dashed line, predicts the change in transit trips based on changes in all factors except vehicle access (income, nativity, age, etc.). The second model, represented by the solid line, is identical to the first, but includes changes in automobile access as well. In these models we measure vehicle access as the ratio of vehicles to adults.

The results are dramatic. The models that exclude vehicle access show ridership trending down from 2000 to 2015, but mildly. By contrast, the models that include vehicle ownership estimate a ridership trend that starts at a higher point in 2000 and falls more sharply to a lower point in 2015. This trend is consistent with the idea that lower levels of auto access are associated with much more transit use, while higher levels of auto access are associated with considerably less.

The lines and the changes in the model coefficients (shown in Table 3) also suggest that associations between income and transit use are largely mediated by vehicle access. Income matters largely because it is a means to access automobiles. When vehicle access is not included in the model, the coefficients associated with income are substantially larger,

\footnotetext{
${ }^{9}$ For the most part our CHTS regressions only include variables that also appear in the IPUMS. The lone exception is the licensure variable. We include this in the regression so that the auto ownership variable we apply to the Census data is purged of any influence from licensure.
} 


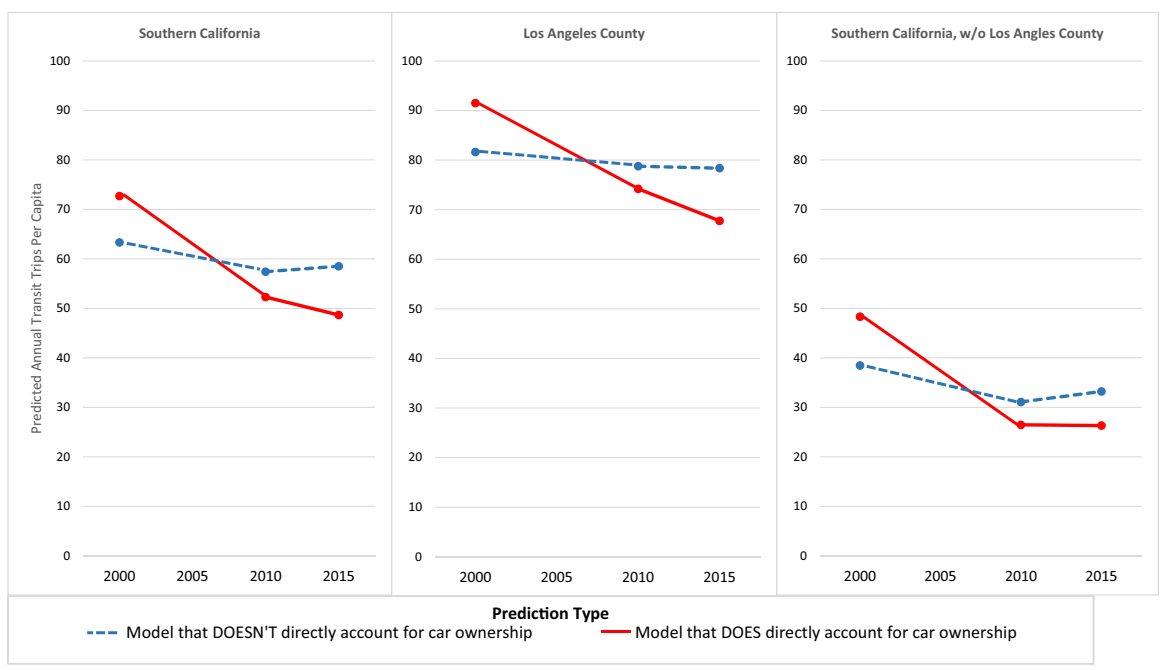

Fig. 4 Relationship between increased vehicle ownership and falling transit trips. Source: 2012 California Household Travel Survey and U.S. Census Bureau

suggesting that income differences in transit ridership shrink once we control for vehicle access. The same holds true for housing tenure (Table 3).

\section{Endogeneity: changes in vehicle access vs changes that prompt vehicle access}

Is vehicle access a cause of recent declines in transit ridership, a correlate of some underlying cause, or some combination of both? We examine this question by investigating changes in the ease of vehicle access and changes in underlying attitudes toward transit. If underlying attitudes toward transit did not change, but vehicles became easier to acquire, then vehicle access may have been a triggering event. If underlying factors did change, however, we cannot rule out that those factors play a role, even if vehicle access also became easier. ${ }^{10}$

Vehicles are easier to acquire when their prices fall or incomes rise. Overall, neither average nor median incomes rose notably in Southern California between 2000 and 2015. LA County's real median household income, for example, was about $\$ 59,000$ in both 2000 and 2015, and was slightly lower in 2010 , during the recession. However, incomes rose among some population groups most likely to use transit. In 2015 newer waves of immigrants (those in the country less than 10 years) had slightly higher mean incomes than recent immigrants in 2000, which might help explain the increase in vehicles among this group (Ruggles et al. various).

Even at constant incomes, however, households can acquire more vehicles, if the effective price of those vehicles falls. The effective price, importantly, is not the sticker price but the actual

\footnotetext{
${ }^{10}$ Dissatisfaction with transit may be associated with peer-norming. If most transit riders primarily associate with other people who primarily ride transit, the relative disadvantage of transit riding may be less salient. If more transit riders begin driving, however, people who remain on transit might become more frustrated with transit service, even if by objective measures service quality does not decline, or even improves. We have no way to measure this, but note that it could be part of the association we capture between vehicle access and transit use.
} 
Table 3 Income and tenure associations with number of transit trips, with and without vehicle controls

\begin{tabular}{|c|c|c|c|c|c|c|}
\hline & \multicolumn{2}{|c|}{ Southern California } & \multicolumn{2}{|c|}{ Los Angeles County } & \multicolumn{2}{|c|}{ SoCal outside LA } \\
\hline & W/out vehicles & Vehicles & W/out vehicles & Vehicles & W/out vehicles & Vehicles \\
\hline \multicolumn{7}{|c|}{ Income (base: 0-25k) } \\
\hline $25-50 \mathrm{k}$ & $\begin{array}{l}-0.565^{* * *} \\
(0.005)\end{array}$ & $\begin{array}{l}-0.071^{* * *} \\
(0.005)\end{array}$ & $\begin{array}{l}-0.612 \text { *** } \\
(0.006)\end{array}$ & $\begin{array}{l}-0.005 \\
(0.006)\end{array}$ & $\begin{array}{l}-0.458^{* * * *} \\
(0.010)\end{array}$ & $\begin{array}{l}-0.492^{* * *} \\
(0.011)\end{array}$ \\
\hline 50-100k & $\begin{array}{l}-1.066^{* * * *} \\
(0.005)\end{array}$ & $\begin{array}{l}-0.216^{* * *} \\
(0.006)\end{array}$ & $\begin{array}{l}-1.064 * * * \\
(0.006)\end{array}$ & $\begin{array}{l}-0.226^{* * *} \\
(0.006)\end{array}$ & $\begin{array}{l}-1.060^{* * *} \\
(0.011)\end{array}$ & $\begin{array}{l}-0.324 * * * \\
(0.011)\end{array}$ \\
\hline $100 \mathrm{k}+$ & $\begin{array}{l}-0.990 * * * \\
(0.006)\end{array}$ & $\begin{array}{l}0.039 * * * \\
(0.006)\end{array}$ & $\begin{array}{l}-1.107 * * * \\
(0.007)\end{array}$ & $\begin{array}{l}-0.065^{* * * *} \\
(0.007)\end{array}$ & $\begin{array}{l}-0.845^{* * * *} \\
(0.012)\end{array}$ & $\begin{array}{l}-0.048^{* * * *} \\
(0.012)\end{array}$ \\
\hline Renter & $\begin{array}{l}1.149 * * * \\
(0.004)\end{array}$ & $\begin{array}{l}0.704 * * * \\
(0.004)\end{array}$ & $\begin{array}{l}1.000 * * * \\
(0.004)\end{array}$ & $\begin{array}{l}0.615 * * * \\
(0.004)\end{array}$ & $\begin{array}{l}1.060^{* * * *} \\
(0.008)\end{array}$ & $\begin{array}{l}0.302 * * * \\
(0.008)\end{array}$ \\
\hline
\end{tabular}

Negative binomial regressions, estimated from CHTS. Full results in Appendix

$* p<0.1 ; * * p<0.05 ; * * * p<0.01$

outlay required to drive the vehicle home. For many people the effective price is heavily influenced by the availability of credit, and as credit became cheaper in the early aughts, households took on more debt. Inflation-adjusted per capita vehicle debt in California rose $91 \%$ between 2000 and 2015, implying that a surge in car ownership was matched by a surge in vehicle debt (Federal Reserve Bank of New York n.d.).

The socioeconomic status of the typical transit rider, however, suggests that for someone on the margin of vehicle ownership the decisive question is not about financing but whether they have a full cash payment for a used car. Table 4, assembled from data in Pierce et al. (2019), shows that low-income households in California overwhelmingly buy used cars with cash, and that fewer than half buy from formal dealers.

Used vehicle prices did fall notably after 2000 (Mannheim Consulting n.d.). Industry analysts suggest that prices fell in part because of changes in financing, but also because automobile leasing peaked in $1999 .{ }^{11}$ Leasing in the 1990s, unlike today, was more common among less popular vehicle models, and aimed primarily at buyers unable to secure financing. As these leases ended in the 2000s, millions of cars flooded the used car market, depressing the average price of used cars overall (Cox Automotive 2018). ${ }^{12}$

The effect of these lower prices may have been augmented by the rise of internet used car sales. The cheapest used vehicles are often sold by owners for cash, and the cash sales benefit both buyers and sellers. Sellers typically get higher prices than they would if they sold or traded in to dealers, while buyers typically pay less to a private party than they would if buying from a dealer. ${ }^{13}$ The benefits of cash sales, however, have traditionally been counterbalanced by high search and uncertainty costs on both sides of the transaction: the buyer and seller need to find each other, and trust that both the transfer of ownership and payment are legitimate. Dealerships provide a coordinating mechanism and transaction security that, for decades, private sales lacked. Searchable internet sales, however, such as those on Craigslist, help resolve the search part of this problem, by making cheap used cars much easier to find.

\footnotetext{
11 Lease originations reached a new absolute peak in 2016, but not a peak as a share of all vehicles sold (Cox Automotive 2018).

12 Used car prices spiked dramatically during the COVID-19 pandemic (Economist 2021).

13 The Kelly Blue Book and similar pricing services estimate three prices for used cars: the purchase price at a car dealer, the lower private party purchase price, and the lower still trade-in price from selling to a dealer.
} 
Table 4 Vehicle purchases by low-income California households. Source: Pierce et al. (2019)

\begin{tabular}{lll}
\hline & Under 25k (\%) & All (\%) \\
\hline Purchase type & & \\
New & 31 & 39 \\
Used & 69 & 61 \\
Seller type & & \\
Formal dealer & 47 & 60 \\
Semi-formal dealer & 10 & 11 \\
From social network & 27 & 20 \\
From internet & 13 & 10 \\
Financing type & & \\
Cash & 62 & 45 \\
Loan for part of cost & 18 & 27 \\
Loan for entirety of cost & 15 & 23 \\
Other & 5 & 5 \\
\hline
\end{tabular}

Semi-formal dealer includes local garage or repair shop, Buy-HerePay-Here-Lot, or On-Street Advertiser

Quantifying the impact of cheaper used cars is difficult. Craigslist began operating in Southern California in 2001, but to our knowledge no publicly-available data track the number of vehicles sold on the site. Figure 5 illustrates used vehicle trends with the best data available, and compares them to trends in vehicle ownership and transit ridership, from 1990 to 2015. We see that the price of used vehicles in the Western US, as measured by the used vehicle consumer price index (CPI), rose substantially over the 1990s, while the national used car finance rate fell slightly and then rose. In 2001, however, both prices and finance rates entered steep declines, and did not bottom out until the Great Recession. At essentially the same time, the share of households without vehicles in Los Angeles also began to fall. Per capita transit use in Los Angeles began falling a few years after that. ${ }^{14}$

\section{Underlying discontent: service quantity and quality}

We now turn to the question of whether transit became absolutely or relatively less attractive (controlling for vehicle access) during our study period. We examine this question by asking if people saw less value in transit. Transit can fall in value if service stays constant while fares rise, or if fares stay constant (or rise) while service declines. Service can decline, in turn, if quantity falls (fewer routes are operated or frequency on them declines) or quality falls (reliability declines, or passengers feel less comfortable or safe). We take up these factors in turn.

On average, inflation-adjusted fares per boarding were flat in both Los Angeles County and Southern California between 2000 and 2015 . $^{15}$ This stability was not uniform-fares

\footnotetext{
${ }^{14}$ Figure 5 shows the share of households without vehicles falling after 2000, while the finance rates and prices started falling in 2001. This discrepancy may be an artifact of interpolation. Census data on household vehicle ownership are not available annually before 2006, so the line is interpolated between 1990, 2000 , and 2006.

15 We measure fares as total fare revenue divided by total boardings. This calculation does not capture the myriad fares paid by many different riders, some of whom pay lower rates than others as a result of monthly passes, discounts due to age or disability, etc. Fares per mile traveled fell slightly over this time, but fares per boarding are probably more salient to riders.
} 


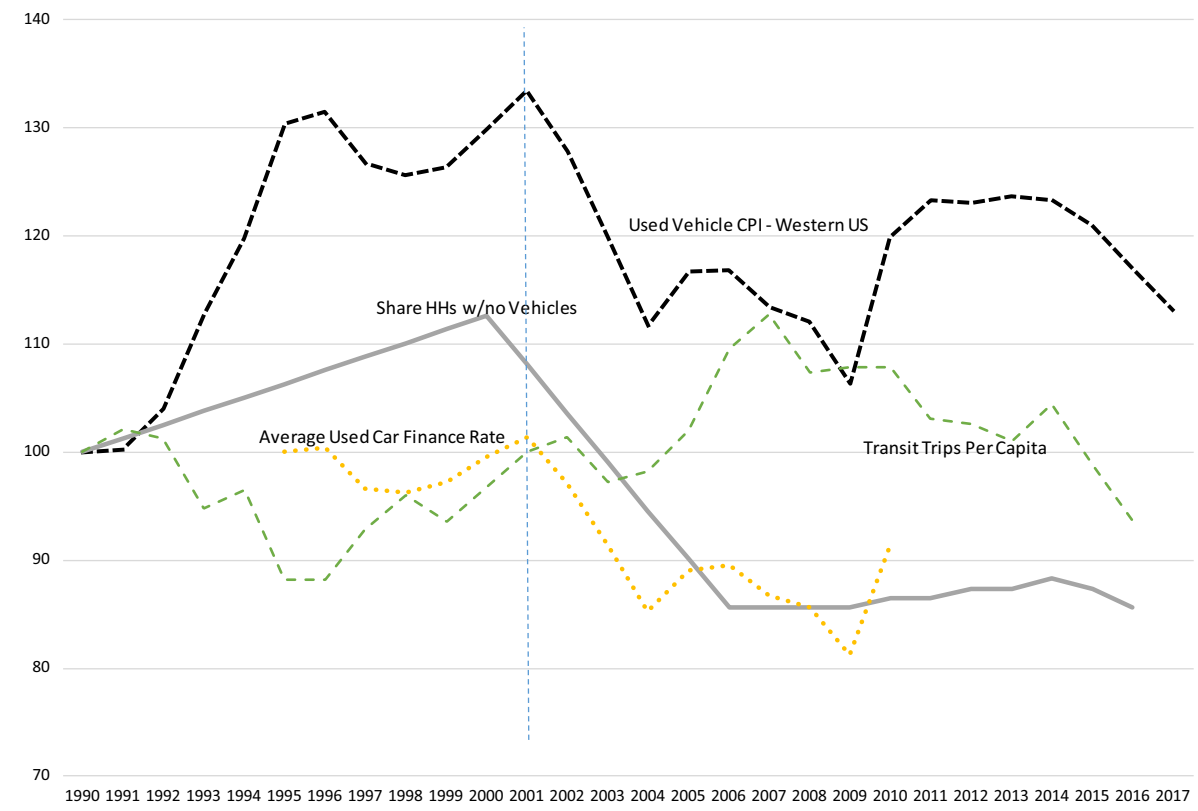

Fig. 5 Vehicle access and transit ridership 1990-2018. Sources: US Bureau of Labor Statistics various years (used car CPI) Board of Governors of the Federal Reserve various (used car finance rate), US Census Bureau various (households without vehicles), National Transit Database (transit trips per capita)

for the Orange County Transportation Authority (OCTA) and Santa Monica Big Blue Bus increased about 50\% between 2002 and 2016, and this may have influenced ridership on those operators. But the largest operator, LA Metro, saw substantial ridership losses despite no real increase in average fare paid per boarding.

Service quantity, in both Southern California and Los Angeles County, appears to have risen, not fallen, as ridership declined. Transit vehicle revenue hours (VRH) in Southern California increased from both 2005 to 2016 and 2010 to 2016, and did so on operators large and small. VRH grew least among the operators that lost the most riders, but grew nevertheless. $^{16}$

\footnotetext{
${ }^{16}$ Service levels can also be measured through vehicle revenue miles (VRM). VRM in Southern California did decline from 2000 to 2015, leading some observers to blame falling VRM for ridership declines (Boisjoly et al. 2018; Hertz 2015; Harrison 2017). But VRM alone is hard to interpret. VRM captures the distance that transit vehicles cover, while VRH measures the amount of time they operate. VRM will as a result have a higher variance than VRH, because the time between stops varies less than the distance. For instance, compare a dozen stops spaced far apart in uncongested suburbs to closely-spaced stops in a congested urban center. The miles covered on the two routes will differ much more than the time required to serve them. Falling VRM can therefore indicate reduced service quantity, but also indicate degraded quality (transit vehicles operating in higher levels of congestion) or that transit operators have strategically increased local rather than express service, and/or redirected service from outlying to central areas. In these latter scenarios a vehicle might be moved to areas where service quality is lower, in an effort to make service quality better. Distinguishing among all these possibilities requires examining VRH. If VRM and VRH fall at roughly the same rate, then service quantity is likely falling absolutely. But VRM fell in Southern California while VRH did not, which suggests that some combination of increased traffic delays and redeployed service-rather than service cuts—were at play.
} 
Service quality is harder to measure than quantity, but does appear to have deteriorated as ridership declined. Region-wide bus vehicle speeds fell 13\% from 2000 to 2015, most likely due to worsening congestion. ${ }^{17}$ Falling speeds could reduce bus ridership. But speed did not fall nearly as much on rail: rail speeds fell only $2 \%$, and rail service maintained a near-perfect on-time record from 2000 to 2016. Rail ridership, however, fell alongside bus ridership, suggesting that speed deterioration alone cannot be responsible for falling ridership. ${ }^{18}$

Rail may have suffered a different form of service degradation (which may affect buses as well): an increasing sense of discomfort on the part of passengers. Some journalistic accounts, as well as reports from within LA Metro, suggest that many homeless people in LA use transit vehicles and stations (especially rail vehicles and stations) for shelter and protection (Nelson 2018b; Haskell 2019; Loukaitou-Sideris et al 2021). If potential riders find the presence of homeless people on or near transit disturbing or threatening, transit use becomes less appealing - regardless of whether homeless people are in fact a threat.

Data to substantiate this narrative are suggestive but fragmentary. Counts of the homeless population in LA County, while always prone to error, suggest a dramatic spike in not just unhoused people but unsheltered, chronically homeless people in particular. Unsheltered homeless people are more likely to be in or near transit, and chronically homeless people, because they are more likely to struggle with addiction or mental illness, are more likely to be perceived as threatening by others. Between 2013 and 2017, the estimated homeless population in LA County rose from 39,000 to 58,000, the share of the homeless who lacked shelter rose from 64 to $74 \%$, the share who were chronically homeless rose from 17 to $28 \%$, and the share of the unsheltered who were chronically homeless rose from 26 to 38\% (LAHSA various). Moreover, while the share of Metro riders who reported that they felt unsafe on transit did not change much, former riders surveyed by Metro report riding less because they felt unsafe. ${ }^{19}$ Nevertheless, no solid data link these feelings to an increased presence of homeless people on or near transit. While we cannot discount this potential cause, we also cannot confirm it.

\section{Other potential factors}

Poverty suburbanized during the 2000s, which may have reduced transit use. Transit in Southern California is heavily supplied in a small proportion of places, and heavily used by a small proportion of people. If the small group of regular transit users becomes less likely to live in the small number of places where transit service is frequent, perhaps because dense neighborhoods gentrify, then transit use could fall.

\footnotetext{
17 We measure quality with speed data. Transit agencies also measure quality with self-reported "reliability," or the proportion of on-time arrivals. LA Metro's reliability improved dramatically from 2008 to 2016 (Flowers and Snoble 2008; Mendelson 2015). But reliability reflects both the conditions vehicles face and the schedules they follow-and the operators set the schedules. Operators can therefore improve reliability by meeting the existing schedule more often or by changing the schedule to make it easier to meet. Only one of these manifests as better service for the passenger, and we lack the data to differentiate between them.

18 The oldest currently operating LA rail line was taken offline entirely in 2019 for maintenance, following service cutbacks. Ridership losses predate these problems.

19 The share of riders who report feeling unsafe comes from LA Metro's Annual Rider Surveys. LA Metro never published the survey of former riders, but it is available from the authors on request and is mentioned in Nelson (2018b).
} 
The IPUMs data in our regressions do not offer neighborhood-level granularity, so we cannot know where riders lived or moved to or from. It is possible, therefore, that some of the increased vehicle access we see among lower-income people was motivated in part by being forced to move away from higher-quality transit. This question, of whether neighborhood change influences transit use, deserves more research.

A second potential factor is fuel prices. Fuel prices in Southern California climbed dramatically from 1998 to 2008, plunged, rose again to a peak in 2012, then fell dramatically (Manville et al. 2018). Existing research suggests that falling fuel prices have a large impact on volumes of driving, and a real but more modest impact on transit use (Iseki and Ali 2015). Cheaper fuel can only trigger less transit use among people who have vehicle access, and in almost every year since 2010 over-two thirds of LA Metro riders, and over $75 \%$ of LA Metro bus riders, report lacking access to a vehicle. It is possible, of course, that falling fuel prices encouraged the minority of riders with vehicle access to ride less, and also tipped some marginal travelers - those teetering between driving and transitback into their cars. Per capita transit use in Southern California has been mostly falling since 2007, and it fell between 2009 and 2011 when fuel prices rose sharply. Nevertheless, we cannot rule out falling fuel prices as a contributor to falling transit ridership.

The final factor we consider is ridehailing: Lyft and Uber. What little we know about ridehailing users suggests that most are not regular transit riders (Clewlow and Mishra 2017; Feigon and Murphy 2016; Rayle et al 2016). Nevertheless, ridehail service could both complement and compete with transit. On one hand, some would-be transit riders might be drawn away by ridehail service, since it can offer the convenience of automobile travel to people who lack automobiles of their own. Ridehailing is, in this sense, just another form of vehicle access. On the other hand, ridehail service could increase transit use by improving access to and from stops and stations, and by offering transit riders a form of insurance. If some people drive rather than ride transit because they worry about emergencies where they might need a car (for instance, sick children needing transportation home from school), then the presence of ridehail service can lower transit's perceived risk, and make it more attractive.

Ridehail data are privately-held, so measuring these effects is difficult, and beyond the scope of our inquiry. The relatively few studies that examine ridehail impacts on transit yield mixed results. Hall et al. (2018) analyze all US MSAs from 2004 to 2015 and find that Uber use complements transit ridership on average, although the service's impact varies substantially by the size of the both the metropolitan area and the transit agency. Graehler et al. (2019), in contrast, analyzed only 22 US urbanized areas, but did so from 2002 to 2018, and thus included years when TNC use grew most. They find that the entry of Uber has diminished US transit ridership.

We cannot rule out ridehailing reducing ridership in Southern California. But while ridehail firms could contribute to the problem, they cannot explain it entirely. Per capita transit ridership began falling in 2007. Uber was not founded until 2009, as a car service, and did not begin ridehail operations until 2012 (when Lyft also launched). Neither Uber nor Lyft arrived in Los Angeles until 2013, and neither launched lower-cost shared rides until 2014. Both firms grew dramatically after 2015 , by which point transit was already declining absolutely. 


\section{Conclusion}

Transit ridership fell sharply across the United States in the 2010s, and perhaps nowhere more notably than Los Angeles, where large investments in service coincided with steep declines in pre-pandemic patronage. What caused these losses? We suggest that these pre-COVID declines in Southern California ridership were strongly associated with increases in vehicle access, and that this new vehicle access may have itself been enabled by the falling price of used cars. To be sure, vehicle access is unlikely the lone culprit. Ridehail firms, gas prices, and changing service quality may have also played a role. Vehicle access, however, matches the timing of transit's pre-COVID decline, and the relationship between vehicle access and ridership is robust to a host of controls.

Most important, rising vehicle access as a source of lost ridership makes sense conceptually. Los Angeles, like most of the US, has long been designed for automobiles. For that reason, most people in LA who can afford cars buy and use them. Transit is reserved largely for people with limited access to vehicles, and transit riders - by dint of using public transportation in a landscape laid out for private transportation — suffer diminished mobility and access. This basic fact - the structural advantage of the auto over transit— has not changed much during our study period, and indeed to the extent it has changed it has done so slightly in transit's favor, as congestion has made auto access fall. What did change, however, was the ease with which transit riders could buy a vehicle, escape transit's confines, and enjoy the same access and mobility as the driving majority. Our evidence suggests that vehicles became cheaper and easier to find, and low-income households began adding them, right before transit ridership started ticking down. And because vehicle ownership is "sticky" - once people have cars, they tend to drive themeven a onetime surge in vehicle ownership could portend an extended slump in ridership.

Not every large urban region resembles Los Angeles. Indeed, many of the nation's largest regions, which hold the most transit riders, differ from it profoundly. American transit ridership is concentrated in large urban centers not designed around cars. This concentration makes "national" transit ridership difficult to analyze. Nevertheless, Los Angeles holds lessons for the hundreds of urban areas where transit is primarily a safety net. These are not the places that hold the most riders, but they are most places.

When transit is primarily a social service, improvements in low-income mobility can threaten transit's viability. Transit works better, and transit agencies fare better, when more people ride. But riding in most places is usually inferior to driving. In places designed for the car, transit's viability thus depends on many low-income people having constrained mobility. From an equity perspective, this situation might create an uncomfortable tension. The same egalitarian impulse that recognizes transit's importance to low-income people should also see the value of low-income people acquiring cars and graduating away from it. If transit is important because it provides a safety net level of mobility for the vulnerable, then vehicle acquisition by low-income people, which dramatically improves their mobility, should be important as well. 
Recognizing that cars can have high value for former transit riders is different from seeing falling transit ridership as socially costless. Driving contributes to a plethora of social problems. Also, not every rider can acquire a car, and as ridership falls, service might deteriorate for those still on transit. Lower-income travelers who acquire cars and leave transit improve their mobility and access, but also-by imposing costs on transit agencies - create problems for the people who remain.

The problem here lies not with the behavior of the people buying cars, but with the broader circumstances that make transit a mode of last resort, and driving a mode of first resort. In urban areas where buses must contend with traffic, where roads are wide and free, where gasoline is only modestly-taxed, and where parking is abundant and densities low, transit ridership will be comprised disproportionately of disadvantaged people, many of them yearning to drive. These yearnings will mean that transit, the economic lifeline on which its riders collectively rely, will also be perversely vulnerable to its riders' individual economic success. If driving were less privileged and transit more effective, transit riders would be less uniformly low-income, and this dilemma would diminish, and perhaps disappear.

That last point is important, so we make it one final way. The fact of America's auto-orientation makes the question of why transit ridership fell before COVID-19 fundamentally different from the question of how to make it rise afterward. Analysts and agencies (including us, in this article) often focus on why the small share of people who regularly use transit began using it less. This is an important question, but it too easily takes as given the enormous structural benefits public policy bestows on private driving. Asking how to make transit ridership rise, in contrast, expands the focus beyond current riders who are riding less, and puts more emphasis on current drivers who never ride. In doing so it also puts the structural advantages of driving on the table. If reducing or removing those benefits - through parking and congestion charges, bus-only lanes, and higher density development—nudged even small shares of current drivers onto transit vehicles, ridership would rise dramatically.

\section{Appendix: Full descriptive statistics and regression output}

See Tables 5 and 6. 
Table 5 Descriptive statistics, CHTS regression sample: share taking transit on survey day. Source: California Department of Transportation (2012)

\begin{tabular}{|c|c|c|c|}
\hline & $\begin{array}{l}\text { Six } \\
\text { County South- } \\
\text { ern California } \\
\text { Region }\end{array}$ & $\begin{array}{l}\text { Los Angeles } \\
\text { County Alone }\end{array}$ & $\begin{array}{l}\text { Southern } \\
\text { California } \\
\text { outside LA } \\
\text { County }\end{array}$ \\
\hline All (weighted) & 4.8 & 6.9 & 2.4 \\
\hline All (unweighted) & 3.7 & 5.6 & 1.8 \\
\hline \multicolumn{4}{|l|}{ Age } \\
\hline$<16$ & 3.2 & 4.7 & 1.6 \\
\hline $16-25$ & 7.3 & 10.6 & 3.5 \\
\hline $26-45$ & 5.2 & 7.3 & 2.6 \\
\hline $46-65$ & 4.9 & 6.9 & 2.4 \\
\hline $66-79$ & 4.2 & 6 & 2 \\
\hline $80+$ & 2.3 & 3.3 & 1.1 \\
\hline \multicolumn{4}{|l|}{ Race/ethnicity } \\
\hline White & 2.2 & 3.2 & 1.3 \\
\hline Asian & 3.1 & 4.2 & 1.2 \\
\hline Hispanic & 7.1 & 9.8 & 3.7 \\
\hline Af. Am & 9.3 & 11 & 4.4 \\
\hline Other race & 3.5 & 2.9 & 4.3 \\
\hline \multicolumn{4}{|l|}{ Immigrant tenure } \\
\hline Native born & 3.8 & 5.7 & 1.8 \\
\hline $0-5$ years & 13.8 & 16.4 & 8.5 \\
\hline $5-10$ years & 10.4 & 13.5 & 5 \\
\hline $10-20$ years & 11 & 14.3 & 6.3 \\
\hline 20-30 years & 7.9 & 9.8 & 5.1 \\
\hline $30+$ years & 5 & 6.3 & 2.8 \\
\hline \multicolumn{4}{|l|}{ Income } \\
\hline$\$ 0-\$ 25 \mathrm{k}$ & 11.4 & 15.2 & 5.9 \\
\hline$\$ 25 \mathrm{k}-\$ 50 \mathrm{k}$ & 5.3 & 7.5 & 2.6 \\
\hline$\$ 50 \mathrm{k}-\$ 100 \mathrm{k}$ & 2 & 3 & 1 \\
\hline$\$ 100 \mathrm{k}+$ & 1.7 & 2.3 & 1.1 \\
\hline \multicolumn{4}{|c|}{ Vehicle-to-adult ratio } \\
\hline 0 vehicles & 28.6 & 31.5 & 21.5 \\
\hline $0.01-0.49$ & 13.2 & 16.4 & 7.3 \\
\hline $0.5 \mathrm{veh} /$ adult & 6.4 & 8.9 & 2.9 \\
\hline $0.51-0.99$ & 2.2 & 2.8 & 1.6 \\
\hline $1 \mathrm{veh} /$ adult & 1.2 & 1.7 & 0.6 \\
\hline $1.01-1.5$ & 1.4 & 1.7 & 1.1 \\
\hline$>1.5$ & 1.9 & 3.1 & 0.6 \\
\hline \multicolumn{4}{|l|}{ Licensure } \\
\hline License & 2.6 & 3.8 & 1.2 \\
\hline No license & 18.2 & 22.2 & 11.4 \\
\hline Non-adult & 3.2 & 4.7 & 1.6 \\
\hline$N$ & 35,875 & 17,830 & 18,045 \\
\hline
\end{tabular}


Table 6 Associations with number of transit trips, negative binomial regressions

\begin{tabular}{|c|c|c|c|c|c|c|}
\hline & \multicolumn{2}{|c|}{$\begin{array}{l}\text { Six County Southern Cali- } \\
\text { fornia Region }\end{array}$} & \multicolumn{2}{|c|}{ Los Angeles County Alone } & \multicolumn{2}{|c|}{$\begin{array}{l}\text { Southern California outside } \\
\text { LA County }\end{array}$} \\
\hline & $\begin{array}{l}\text { W/out vehi- } \\
\text { cles }\end{array}$ & Vehicles & $\begin{array}{l}\text { W/out vehi- } \\
\text { cles }\end{array}$ & Vehicles & $\begin{array}{l}\text { W/out vehi- } \\
\text { cles }\end{array}$ & Vehicles \\
\hline \multicolumn{7}{|l|}{ Age (base: 0-15) } \\
\hline $16-25$ & $\begin{array}{l}1.250 * * * \\
(0.006)\end{array}$ & $\begin{array}{l}1.190 * * * \\
(0.005)\end{array}$ & $\begin{array}{l}1.176^{* * * *} \\
(0.007)\end{array}$ & $\begin{array}{l}1.124 * * * \\
(0.006)\end{array}$ & $\begin{array}{l}1.404 * * * \\
(0.012)\end{array}$ & $\begin{array}{l}1.166^{* * * *} \\
(0.011)\end{array}$ \\
\hline $26-35$ & $\begin{array}{l}0.637 * * * \\
(0.006)\end{array}$ & $\begin{array}{l}0.615 * * * \\
(0.006)\end{array}$ & $\begin{array}{l}0.729 * * * \\
(0.007)\end{array}$ & $\begin{array}{l}0.666^{* * * *} \\
(0.007)\end{array}$ & $\begin{array}{l}-0.099 * * * \\
(0.013)\end{array}$ & $\begin{array}{l}-0.094^{* * * *} \\
(0.013)\end{array}$ \\
\hline $36-45$ & $\begin{array}{l}0.825 * * * \\
(0.006)\end{array}$ & $\begin{array}{l}0.901 * * * \\
(0.006)\end{array}$ & $\begin{array}{l}0.772 * * * \\
(0.007)\end{array}$ & $\begin{array}{l}0.840 * * * \\
(0.007)\end{array}$ & $\begin{array}{l}0.827 * * * \\
(0.013)\end{array}$ & $\begin{array}{l}0.862 * * * \\
(0.013)\end{array}$ \\
\hline $46-55$ & $\begin{array}{l}0.854 * * * \\
(0.006)\end{array}$ & $\begin{array}{l}0.855^{* * * *} \\
(0.006)\end{array}$ & $\begin{array}{l}0.860 * * * \\
(0.007)\end{array}$ & $\begin{array}{l}0.839 * * * \\
(0.007)\end{array}$ & $\begin{array}{l}0.772 * * * \\
(0.012)\end{array}$ & $\begin{array}{l}0.714 * * * \\
(0.012)\end{array}$ \\
\hline $56-65$ & $\begin{array}{l}1.029 * * * \\
(0.007)\end{array}$ & $\begin{array}{l}1.048 * * * \\
(0.007)\end{array}$ & $\begin{array}{l}1.038 * * * \\
(0.008)\end{array}$ & $\begin{array}{l}0.964 * * * \\
(0.008)\end{array}$ & $\begin{array}{l}0.799 * * * \\
(0.014)\end{array}$ & $\begin{array}{l}1.016^{* * * *} \\
(0.013)\end{array}$ \\
\hline $66-79$ & $\begin{array}{l}0.615^{* * * *} \\
(0.008)\end{array}$ & $\begin{array}{l}0.677 * * * \\
(0.007)\end{array}$ & $\begin{array}{l}0.609 * * * \\
(0.009)\end{array}$ & $\begin{array}{l}0.666^{* * * *} \\
(0.008)\end{array}$ & $\begin{array}{l}0.356^{* * * *} \\
(0.015)\end{array}$ & $\begin{array}{l}0.371 * * * \\
(0.016)\end{array}$ \\
\hline $80+$ & $\begin{array}{l}0.106^{* * *} \\
(0.011)\end{array}$ & $\begin{array}{l}-0.119 * * * \\
(0.011)\end{array}$ & $\begin{array}{l}0.159 * * * \\
(0.013)\end{array}$ & $\begin{array}{l}-0.054 * * * \\
(0.013)\end{array}$ & $\begin{array}{l}-0.258 * * * \\
(0.023)\end{array}$ & $\begin{array}{l}-0.527 * * * \\
(0.024)\end{array}$ \\
\hline Immigrant & $\begin{array}{l}1.520 * * * \\
(0.017)\end{array}$ & $\begin{array}{l}1.598^{* * * *} \\
(0.016)\end{array}$ & $\begin{array}{l}1.175^{* * * *} \\
(0.019)\end{array}$ & $\begin{array}{l}1.257 * * * \\
(0.018)\end{array}$ & $\begin{array}{l}2.027 * * * \\
(0.039)\end{array}$ & $\begin{array}{l}1.591 * * * \\
(0.036)\end{array}$ \\
\hline Female & $\begin{array}{l}-0.167 * * * \\
(0.004)\end{array}$ & $\begin{array}{l}-0.132^{* * * *} \\
(0.004)\end{array}$ & $\begin{array}{l}-0.191^{* * * *} \\
(0.004)\end{array}$ & $\begin{array}{l}-0.176^{* * * *} \\
(0.004)\end{array}$ & $\begin{array}{l}-0.050 * * * \\
(0.007)\end{array}$ & $\begin{array}{l}0.023 * * * \\
(0.007)\end{array}$ \\
\hline \multicolumn{7}{|c|}{ Income (base: 0-25k) } \\
\hline $25-50 \mathrm{k}$ & $\begin{array}{l}-0.565^{* * * *} \\
(0.005)\end{array}$ & $\begin{array}{l}-0.071 * * * \\
(0.005)\end{array}$ & $\begin{array}{l}-0.612^{* * * *} \\
(0.006)\end{array}$ & $\begin{array}{l}-0.005 \\
(0.006)\end{array}$ & $\begin{array}{l}-0.458 * * * \\
(0.010)\end{array}$ & $\begin{array}{l}-0.492 * * * \\
(0.011)\end{array}$ \\
\hline $50-100 k$ & $\begin{array}{l}-1.066^{* * * *} \\
(0.005)\end{array}$ & $\begin{array}{l}-0.216^{* * * *} \\
(0.006)\end{array}$ & $\begin{array}{l}-1.064 * * * \\
(0.006)\end{array}$ & $\begin{array}{l}-0.226^{* * * *} \\
(0.006)\end{array}$ & $\begin{array}{l}-1.060^{* * * *} \\
(0.011)\end{array}$ & $\begin{array}{l}-0.324 * * * \\
(0.011)\end{array}$ \\
\hline $100 \mathrm{k}+$ & $\begin{array}{l}-0.990 * * * \\
(0.006)\end{array}$ & $\begin{array}{l}0.039 * * * \\
(0.006)\end{array}$ & $\begin{array}{l}-1.107^{* * * *} \\
(0.007)\end{array}$ & $\begin{array}{l}-0.065^{* * * *} \\
(0.007)\end{array}$ & $\begin{array}{l}-0.845^{* * * *} \\
(0.012)\end{array}$ & $\begin{array}{l}-0.048 * * * \\
(0.012)\end{array}$ \\
\hline \multicolumn{7}{|c|}{ Race/Eth (base: white) } \\
\hline Black & $\begin{array}{l}1.212^{* * * *} \\
(0.006)\end{array}$ & $\begin{array}{l}0.979 * * * \\
(0.006)\end{array}$ & $\begin{array}{l}1.047 * * * \\
(0.006)\end{array}$ & $\begin{array}{l}0.777 * * * \\
(0.006)\end{array}$ & $\begin{array}{l}0.492 * * * \\
(0.016)\end{array}$ & $\begin{array}{l}0.833^{* * * *} \\
(0.014)\end{array}$ \\
\hline Asian & $\begin{array}{l}0.279 * * * \\
(0.008)\end{array}$ & $\begin{array}{l}0.072 * * * \\
(0.008)\end{array}$ & $\begin{array}{l}0.197 * * * \\
(0.009)\end{array}$ & $\begin{array}{l}-0.040 * * * \\
(0.009)\end{array}$ & $\begin{array}{l}-0.160 * * * \\
(0.018)\end{array}$ & $\begin{array}{l}-0.260 * * * \\
(0.018)\end{array}$ \\
\hline Hispanic & $\begin{array}{l}0.560 * * * \\
(0.005)\end{array}$ & $\begin{array}{l}0.451 * * * \\
(0.005)\end{array}$ & $\begin{array}{l}0.529 * * * \\
(0.006)\end{array}$ & $\begin{array}{l}0.408 * * * \\
(0.005)\end{array}$ & $\begin{array}{l}0.361 * * * \\
(0.009)\end{array}$ & $\begin{array}{l}0.246^{* * * *} \\
(0.009)\end{array}$ \\
\hline Other race & $\begin{array}{l}-0.888^{* * * *} \\
(0.033)\end{array}$ & $\begin{array}{l}-1.108 * * * \\
(0.035)\end{array}$ & $\begin{array}{l}-0.834 * * * \\
(0.038)\end{array}$ & $\begin{array}{l}-1.150^{* * * *} \\
(0.042)\end{array}$ & $\begin{array}{l}-0.770 * * * \\
(0.059)\end{array}$ & $\begin{array}{l}-0.722 * * * \\
(0.057)\end{array}$ \\
\hline Not employed & $\begin{array}{l}-0.100^{* * * *} \\
(0.004)\end{array}$ & $\begin{array}{l}-0.217 * * * \\
(0.004)\end{array}$ & $\begin{array}{l}-0.041^{* * * *} \\
(0.004)\end{array}$ & $\begin{array}{l}-0.144 * * * \\
(0.004)\end{array}$ & $\begin{array}{l}-0.252^{* * * *} \\
(0.008)\end{array}$ & $\begin{array}{l}-0.381^{* * * *} \\
(0.008)\end{array}$ \\
\hline With disability & $\begin{array}{l}0.307 * * * \\
(0.006)\end{array}$ & $\begin{array}{l}0.071 * * * \\
(0.006)\end{array}$ & $\begin{array}{l}0.059 * * * \\
(0.007)\end{array}$ & $\begin{array}{l}-0.235^{* * * *} \\
(0.006)\end{array}$ & $\begin{array}{l}0.932 * * * \\
(0.012)\end{array}$ & $\begin{array}{l}0.851 * * * \\
(0.011)\end{array}$ \\
\hline Renter & $\begin{array}{l}1.149 * * * \\
(0.004)\end{array}$ & $\begin{array}{l}0.704 * * * \\
(0.004)\end{array}$ & $\begin{array}{l}1.000 * * * \\
(0.004)\end{array}$ & $\begin{array}{l}0.615^{* * * *} \\
(0.004)\end{array}$ & $\begin{array}{l}1.060 * * * \\
(0.008)\end{array}$ & $\begin{array}{l}0.302 * * * \\
(0.008)\end{array}$ \\
\hline \multicolumn{7}{|c|}{ Years in US (base: Native) } \\
\hline $10-20$ years & $\begin{array}{l}-1.020 * * * \\
(0.014)\end{array}$ & $\begin{array}{l}-0.867 * * * \\
(0.012)\end{array}$ & $\begin{array}{l}-0.791^{* * * *} \\
(0.015)\end{array}$ & $\begin{array}{l}-0.741^{* * * *} \\
(0.014)\end{array}$ & $\begin{array}{l}-1.247^{* * * *} \\
(0.032)\end{array}$ & $\begin{array}{l}-0.564 * * * \\
(0.029)\end{array}$ \\
\hline $20-30$ years & $\begin{array}{l}-1.027 * * * \\
(0.014)\end{array}$ & $\begin{array}{l}-0.892 * * * \\
(0.013)\end{array}$ & $\begin{array}{l}-0.792 * * * \\
(0.015)\end{array}$ & $\begin{array}{l}-0.773 * * * \\
(0.014)\end{array}$ & $\begin{array}{l}-1.621 * * * \\
(0.033)\end{array}$ & $\begin{array}{l}-0.975^{* * * *} \\
(0.029)\end{array}$ \\
\hline
\end{tabular}


Table 6 (continued)

\begin{tabular}{|c|c|c|c|c|c|c|}
\hline & \multicolumn{2}{|c|}{$\begin{array}{l}\text { Six County Southern Cali- } \\
\text { fornia Region }\end{array}$} & \multicolumn{2}{|c|}{ Los Angeles County Alone } & \multicolumn{2}{|c|}{$\begin{array}{l}\text { Southern California outside } \\
\text { LA County }\end{array}$} \\
\hline & $\begin{array}{l}\text { W/out vehi- } \\
\text { cles }\end{array}$ & Vehicles & $\begin{array}{l}\text { W/out vehi- } \\
\text { cles }\end{array}$ & Vehicles & $\begin{array}{l}\text { W/out vehi- } \\
\text { cles }\end{array}$ & Vehicles \\
\hline $30+$ years & $\begin{array}{l}-1.308^{* * * *} \\
(0.014)\end{array}$ & $\begin{array}{l}-1.126^{* * * *} \\
(0.013)\end{array}$ & $\begin{array}{l}-1.109 * * * \\
(0.015)\end{array}$ & $\begin{array}{l}-0.846^{* * * *} \\
(0.014)\end{array}$ & $\begin{array}{l}-1.842^{* * * *} \\
(0.033)\end{array}$ & $\begin{array}{l}-1.989 * * * \\
(0.030)\end{array}$ \\
\hline $\begin{array}{l}\text { Less than } \\
10 \text { years }\end{array}$ & $\begin{array}{l}-1.117 * * * \\
(0.015)\end{array}$ & $\begin{array}{l}-0.754 * * * \\
(0.014)\end{array}$ & $\begin{array}{l}-0.847 * * * \\
(0.017)\end{array}$ & $\begin{array}{l}-0.465 * * * \\
(0.015)\end{array}$ & $\begin{array}{l}-2.068 * * * \\
(0.038)\end{array}$ & $\begin{array}{l}-1.862 * * * \\
(0.035)\end{array}$ \\
\hline \multicolumn{7}{|c|}{ HH Adults (base: 1 adult) } \\
\hline 2 adults & $\begin{array}{l}-0.256^{* * * *} \\
(0.005)\end{array}$ & & $\begin{array}{l}-0.163^{* * * *} \\
(0.006)\end{array}$ & & $\begin{array}{l}-0.326^{* * * *} \\
(0.012)\end{array}$ & \\
\hline 3 adults & $\begin{array}{l}-0.205^{* * *} \\
(0.006)\end{array}$ & & $\begin{array}{l}-0.068^{* * * *} \\
(0.006)\end{array}$ & & $\begin{array}{l}-0.561 * * * \\
(0.013)\end{array}$ & \\
\hline $4+$ adults & $\begin{array}{l}-0.271 * * * \\
(0.006)\end{array}$ & & $\begin{array}{l}-0.191 * * * \\
(0.007)\end{array}$ & & $\begin{array}{l}-0.534 * * * \\
(0.013)\end{array}$ & \\
\hline \multicolumn{7}{|c|}{ Veh/adult ratio (Base: $>1.5$ ) } \\
\hline 0 vehicles & & $\begin{array}{l}2.118 * * * \\
(0.011)\end{array}$ & & $\begin{array}{l}1.778 * * * \\
(0.013)\end{array}$ & & $\begin{array}{l}3.723 * * * \\
(0.028)\end{array}$ \\
\hline $0.01-0.49$ & & $\begin{array}{l}1.216^{* * *} * \\
(0.011)\end{array}$ & & $\begin{array}{l}0.986 * * * \\
(0.012)\end{array}$ & & $\begin{array}{l}2.130 * * * \\
(0.027)\end{array}$ \\
\hline 0.5 & & $\begin{array}{l}0.694 * * * \\
(0.010)\end{array}$ & & $\begin{array}{l}0.500 * * * \\
(0.012)\end{array}$ & & $\begin{array}{l}1.657 * * * \\
(0.026)\end{array}$ \\
\hline $0.51-0.99$ & & $\begin{array}{l}-0.164^{* * * *} \\
(0.011)\end{array}$ & & $\begin{array}{l}-0.414 * * * \\
(0.012)\end{array}$ & & $\begin{array}{l}0.898 * * * \\
(0.026)\end{array}$ \\
\hline 1 & & $\begin{array}{l}-0.696^{* * * *} \\
(0.010)\end{array}$ & & $\begin{array}{l}-0.826^{* * * *} \\
(0.012)\end{array}$ & & $\begin{array}{l}0.052 * * \\
(0.026)\end{array}$ \\
\hline $1.01-1.5$ & & $\begin{array}{l}-0.160^{* * *} \\
(0.012)\end{array}$ & & $\begin{array}{l}-0.288^{* * * *} \\
(0.014)\end{array}$ & & $\begin{array}{l}0.652 * * * \\
(0.028)\end{array}$ \\
\hline $\begin{array}{l}\text { Immigrant } * \\
\text { female }\end{array}$ & $\begin{array}{l}0.471 * * * \\
(0.007)\end{array}$ & $\begin{array}{l}0.386^{* * * *} \\
(0.007)\end{array}$ & $\begin{array}{l}0.426^{* * * *} \\
(0.008)\end{array}$ & $\begin{array}{l}0.414 * * * \\
(0.007)\end{array}$ & $\begin{array}{l}0.563 * * * \\
(0.015)\end{array}$ & $\begin{array}{l}0.402 * * * \\
(0.014)\end{array}$ \\
\hline $\begin{array}{l}\text { Immigrant } * \\
100 \mathrm{k}+\end{array}$ & $\begin{array}{l}0.199 * * * \\
(0.012)\end{array}$ & $\begin{array}{l}0.019 * \\
(0.011)\end{array}$ & $\begin{array}{l}0.119^{* * * *} \\
(0.013)\end{array}$ & $\begin{array}{l}-0.154 * * * \\
(0.013)\end{array}$ & $\begin{array}{l}1.023 * * * \\
(0.024)\end{array}$ & $\begin{array}{l}1.316^{* * * *} \\
(0.023)\end{array}$ \\
\hline $\begin{array}{l}\text { Immigrant } * \\
50 \mathrm{k}\end{array}$ & $\begin{array}{l}0.092 * * * \\
(0.009)\end{array}$ & $\begin{array}{l}-0.132^{* * *} \\
(0.008)\end{array}$ & $\begin{array}{l}0.250 * * * \\
(0.010)\end{array}$ & $\begin{array}{l}-0.108 * * * \\
(0.009)\end{array}$ & $\begin{array}{l}-0.190 * * * \\
(0.019)\end{array}$ & $\begin{array}{l}0.273 * * * \\
(0.018)\end{array}$ \\
\hline $\begin{array}{l}\text { Immigrant } * \\
100 \mathrm{k}\end{array}$ & $\begin{array}{l}-0.107 * * * \\
(0.010)\end{array}$ & $\begin{array}{l}-0.151 * * * \\
(0.010)\end{array}$ & $\begin{array}{l}-0.007 \\
(0.012)\end{array}$ & $\begin{array}{l}-0.067 * * * \\
(0.011)\end{array}$ & $\begin{array}{l}-0.696^{* * * *} \\
(0.024)\end{array}$ & $\begin{array}{l}-0.372^{* * * *} \\
(0.023)\end{array}$ \\
\hline $\begin{array}{l}\text { Immigrant } * \\
\text { Af. Am }\end{array}$ & $\begin{array}{l}-0.446^{* * * *} \\
(0.026)\end{array}$ & $\begin{array}{l}-0.654 * * * \\
(0.024)\end{array}$ & $\begin{array}{l}-0.714^{* * * *} \\
(0.028)\end{array}$ & $\begin{array}{l}-0.580 * * * \\
(0.026)\end{array}$ & $\begin{array}{l}0.889 * * * \\
(0.059)\end{array}$ & $\begin{array}{l}-0.558 * * * \\
(0.054)\end{array}$ \\
\hline $\begin{array}{l}\text { Immigrant } * \\
\text { Asian }\end{array}$ & $\begin{array}{l}-0.430 * * * \\
(0.014)\end{array}$ & $\begin{array}{l}-0.539 * * * \\
(0.013)\end{array}$ & $\begin{array}{l}-0.364 * * * \\
(0.015)\end{array}$ & $\begin{array}{l}-0.379 * * * \\
(0.015)\end{array}$ & $\begin{array}{l}-1.096^{* * * *} \\
(0.031)\end{array}$ & $\begin{array}{l}-1.269 * * * \\
(0.030)\end{array}$ \\
\hline $\begin{array}{c}\text { Immigrant } * \\
\text { Hispanic }\end{array}$ & $\begin{array}{l}-0.334 * * * \\
(0.012)\end{array}$ & $\begin{array}{l}-0.482 * * * \\
(0.011)\end{array}$ & $\begin{array}{l}-0.382^{* * * *} \\
(0.013)\end{array}$ & $\begin{array}{l}-0.456^{* * * *} \\
(0.013)\end{array}$ & $\begin{array}{l}0.174 * * * \\
(0.025)\end{array}$ & $\begin{array}{l}-0.170^{* * * *} \\
(0.024)\end{array}$ \\
\hline $\begin{array}{c}\text { Immigrant } * \\
\text { other race }\end{array}$ & $\begin{array}{l}0.383 * * * \\
(0.048)\end{array}$ & $\begin{array}{l}0.144 * * * \\
(0.049)\end{array}$ & $\begin{array}{l}-0.499 * * * \\
(0.058)\end{array}$ & $\begin{array}{l}-0.614^{* * * *} \\
(0.063)\end{array}$ & $\begin{array}{l}1.364 * * * \\
(0.090)\end{array}$ & $\begin{array}{l}0.896 * * * \\
(0.085)\end{array}$ \\
\hline Constant & $\begin{array}{l}-3.066^{* * * *} \\
(0.008)\end{array}$ & $\begin{array}{l}-3.879 * * * \\
(0.012)\end{array}$ & $\begin{array}{l}-2.661^{* * * *} \\
(0.009)\end{array}$ & $\begin{array}{l}-3.226^{* * * *} \\
(0.013)\end{array}$ & $\begin{array}{l}-3.398 * * * \\
(0.016)\end{array}$ & $\begin{array}{l}-4.997 * * * \\
(0.028)\end{array}$ \\
\hline $\mathrm{N}$ & 35,710 & 35,710 & 17,736 & 17,736 & 17,974 & 17,974 \\
\hline $\begin{array}{l}\text { Log Likeli- } \\
\text { hood }\end{array}$ & $-4,176,820$ & $-4,038,281$ & $-3,084,798$ & $-2,989,386$ & $-1,019,573$ & $-979,084$ \\
\hline
\end{tabular}


Table 6 (continued)

\begin{tabular}{|c|c|c|c|c|c|c|}
\hline & \multicolumn{2}{|c|}{$\begin{array}{l}\text { Six County Southern Cali- } \\
\text { fornia Region }\end{array}$} & \multicolumn{2}{|c|}{ Los Angeles County Alone } & \multicolumn{2}{|c|}{$\begin{array}{l}\text { Southern California outside } \\
\text { LA County }\end{array}$} \\
\hline & $\begin{array}{l}\text { W/out vehi- } \\
\text { cles }\end{array}$ & Vehicles & $\begin{array}{l}\text { W/out vehi- } \\
\text { cles }\end{array}$ & Vehicles & $\begin{array}{l}\text { W/out vehi- } \\
\text { cles }\end{array}$ & Vehicles \\
\hline $\begin{array}{l}\text { Akaike Inf. } \\
\text { Crit }\end{array}$ & $8,353,710$ & $8,076,638$ & $6,169,667$ & $5,978,849$ & $2,039,216$ & $1,958,245$ \\
\hline
\end{tabular}

${ }^{*} p<0.1 ; * * p<0.05 ; * * * p<0.01$. Regressions estimated from CHTS

Acknowledgements This article is based on a UCLA Institute of Transportation Studies report "Falling Transit Ridership: California and Southern California." We thank Tiffany Chu, Hannah King, Ryan Kurtzman, Joseph Marynak, Esther Huang, and Trevor Thomas for outstanding research assistance. Funding was generously provided by the UC Statewide Transportation Research Program and the US DOT through the Southern California Association of Governments. The usual disclaimers apply.

Author contributions MM: lead writer, project manager. BDT: administrative data on ridership. EB: oversaw regression analysis. AS: regression analysis. MM, BDT and EB jointly designed the research.

Conflict of interest On behalf of all authors, the corresponding author states there is no conflict of interest.

\section{References}

Aaronson, D., Agarwal, S., French, E.: The spending and debt response to minimum wage hikes. Am. Econ. Rev. 102(7), 3111-3139 (2012). https://doi.org/10.1257/aer.102.7.3111

Adams, W., Einav, L., Levin, J.: Liquidity constraints and imperfect information in subprime lending. Am. Econ. Rev. 99(1), 49-84 (2009). https://doi.org/10.1257/aer.99.1.49

Allison, P.: 2012 do we really need zero-inflated models? Statistical Horizons. August 7.

American Public Transportation Association: Transit Fact Book. American Public Transportation Association. Retreived from https://www.apta.com/research-technical-resources/transit-statistics/public-trans portation-fact-book/ (2021a)

American Public Transportation Association: APTA Ridership Trends. TransitApp. Retreived from https:// transitapp.com/APTA. (2021b)

Badger, E., Bui, Q.: The Mystery of the Missing Bus Riders. New York Times. March 13 (2020).

Blumenberg, E., Pierce, G.: Automobile ownership and travel by the poor: evidence from the 2009 National Household Travel Survey. Transp. Res. Rec. 2320, 28-36 (2012). https://doi.org/10.3141/2320-04

Board of Governors of the Federal Reserve System (US): Used car average finance rate at auto finance companies retrieved from FRED, Federal Reserve Bank of St. Louis. https://fred.stlouisfed.org/series/ RIFLPCFAUNM. 23 May 2020

Boisjoly, G., Grisé, E., Maguire, M., Veillette, M.-P., Deboosere, R., Berrebi, E., El-Geneidy, A.: Invest in the ride: a 14 year longitudinal analysis of the determinants of public transport ridership in 25 North American cities. Transp. Res. Part A Policy Pract. 116, 434-445 (2018)

California Department of Transportation: 2010-2012 California Household Travel Survey [dataset]. Author: Sacramento, CA (2012)

Chatman, D.G.: How density and mixed uses at the workplace affect personal commercial travel and commute mode choice. Transp. Res. Rec. 1831, 193-201 (2003)

Chatman, D.G.: Explaining the "immigrant effect" on auto use: the influences of neighborhoods and preferences. Transportation 41, 441-461 (2014)

Clark, H.M.: Who rides public transportation. American Public Transit Association, Washington, DC (2017)

Clewlow, R.R., Mishra, G.S.: Disruptive transportation: the adoption, utilization, and impacts of ride-hailing in the United States. Institute of Transportation Studies, UC Davis, Davis (2017)

Cox Automotive: 2018 Used Car Market Report \& Outlook. Cox Automotive, Austin (2018) 
Feigon, S., Murphy, C.: Shared Mobility and the Transformation of Public Transit. Shared Use Mobility Center, Chicago (2016)

Flowers, C., Snoble, R.: Metro Regular Board Meeting: Staff Report. LACMTA, Los Angeles, CA. Retrieved from http://media.metro.net/board/Items/2008/06_june/20080618F\&BItem18.pdf (2008)

Freemark, Y.: Transit in Urbanized Areas. The Transport Politic. https:/www.thetransportpolitic.com/datab ook/transit-ridership-in-major-urbanized-areas/. Accessed 14 July 2021

Frost, M.: New York City subway ridership down 92 percent due to coronavirus. Brooklyn Daily Eagle (2020, April 8). https://brooklyneagle.com/articles/2020/04/08/new-york-city-subway-ridership-down92-percent-due-to-coronavirus/

Garr, E.K.: The Suburbanization of Poverty: Trends in Metropolitan America, 2000 to 2008. Brookings Institution, Washington (2010)

Giuliano, G.: Low income, public transit, and mobility. Transp. Res. Rec. 1927, 63-70 (2005). https://doi. org/10.1177/0361198105192700108

Glaeser, E.L., Kahn, M.E., Rappaport, J.: Why do the poor live in cities? The role of public transportation. J. Urban Econ. 63(1), 1-24 (2008)

Graehler, M., Mucci, R., Erhardt, G.: Understanding the Recent Transit Ridership Decline in Major U.S. Cities: Service Cuts or Emerging Modes? 98th Annual Meeting of the Transportation Research Board. Presented at the 98th Annual Meeting of the Transportation Research Board, Washington, D.C. https:// trid.trb.org/view/1572517 (2019)

Hall, J., Palsson, C., Price, J.: Is uber a substitute or complement for public transit? J. Urban Econ. 108, 36-50. Retrieved from https://www.sciencedirect.com/science/article/pii/S0094119018300731 (2018)

Harrison, D.: America's buses lose riders, imperiling their future. Wall Street J. (2017, April 12)

Haskell, J.: Metro riders complain of transients sleeping on trains: "They seem to be wanting to run a homeless shelter". https://abc7.com/5314768/

Hertz, D.: Urban residents aren't abandoning buses; buses are abandoning them. City Observatory, retrieved from https://cityobservatory.org/urban-residents-arent-abandoning-buses-buses-are-abandoning-them/ (2015)

Iseki, H., Ali, R.: Fixed effects panel data analysis of gasoline prices, fare, service supply, and service frequency on transit ridership in Ten U.S. urbanized areas. J. Transp. Res. Board 2537, 71-80 (2015)

King, D.A., Smart, M.J., Manville, M.: The poverty of the carless: toward universal auto access. J. Plann. Educ. Res. 1-18 (2019). https://doi.org/10.1177/0739456X18823252

Kneebone, E.: The Growth and Spread of Concentrated Poverty, 2000 to 2008-2012. Brookings Institution, Washington (2014)

Leininger, L., Levy, H., Schanzenbach, D.: Consequences of SCHIP expansions for household well-being. Forum Health Econ. Policy 13(1), 3 (2010). https://doi.org/10.2202/1558-9544.1201

Levinson, D.: Access Across America. University of Minnesota Center for Transportation Studies, Minneapolis (2013)

Los Angeles Metropolitan Transportation Authority. Measure M: Metro's Plan to Transform Transportation in LA., https://theplan.metro.net/MannheimAutomotive. No Date.

Loukaitou-Sideris, A., Wasserman, J., Caro, R., Ding, H.: Homeless in Transit Environments, vol. I. University of California Institute of Transportation Studies, Berkeley (2021)

Mannheim Used Vehicle Value Index. https://publish.manheim.com/en/services/consulting/used-vehiclevalue-index.html

Manville, M.: Measure M and Potential Transformation of Mobility in Los Angeles. UCLA Institute of Transportation Studies Report. Los Angeles, CA (2019)

Manville, M., Cummins, B.: Why do voters support public transportation? Public Choices Priv. Behav. Transp. 42, 303-332 (2015). https://doi.org/10.1007/s11116-014-9545-2

Manville, M., Taylor, B.D., Blumenberg, E.: Falling transit ridership: California and Southern California. UCLA Institute of Transportation Studies and Southern California Association of Governments, Los Angeles (2018)

Mendelson, A.: How late are LA’s buses and trains? February 19. KPCC (2015, February 19)

Nelson, L.J.: L.A. Metro launches hotline for transit riders who have been harassed, Los Angeles Times (11 January 2017). https://www.latimes.com/local/lanow/la-me-ln-metro-sexual-harassment-20170111story.html

Nelson, L.J.: Ridership on Metro fell to the lowest level in more than a decade last year, Los Angeles (25 January 2018a). https://www.latimes.com/local/lanow/la-me-metro-ridership-20180124-story.html

Nelson, L.J.: As waves of homeless descend onto trains, LA tries a New Strategy, Los Angeles Times (6 April 2018b). https://www.latimes.com/local/lanow/la-me-metro-homeless-20180406-htmlstory.html

Newman, K., Wyly, E.K.: The right to stay put, revisited: gentrification and resistance to displacement in New York City. Urban Stud. 43, 23-57 (2006). https://doi.org/10.1080/00420980500388710 
Owen, A., Murphy, B.: Access across America: transit 2017. University of Minnesota Center for Transportation Studies, Minneapolis (2018a)

Owen, A., Murphy, B.: Access across America: auto 2017. University of Minnesota Center for Transportation Studies, Minneapolis (2018b)

Owen, A., Levinson, D.M.: Access Across America: Transit 2014 Data. University of Minnesota, Minneapolis (2014)

Owen, A., Murphy, B., Levinson, D.: Access across America: auto 2015. University of Minnesota Center for Transportation Studies, Minneapolis (2016)

Parker, J.A., Souleles, N.S., Johnson, D.S., McClelland, R.: Consumer spending and the economic stimulus payments of 2008. Am. Econ. Rev. 103(6), 2530-2553 (2013). https://doi.org/10.1257/aer.103.6.2530

Pierce, G., DeShazo, J., Sheldon, T., McComber, B., Blumenberg, E.: Designing Light-duty Vehicle Incentives for Low- and Moderate-income Households (15RD011). UCLA Luskin Center for Innovation. Retrieved June 22, 2021, from https://ww2.arb.ca.gov/sites/default/files/classic//research/apr/past/ 15rd011.pdf (2019)

Pucher, J., Renne, J.L.: Socioeconomics of urban travel: evidence from the 2001 NHTS. Transp. Q. 57(3), 49-77 (2003)

Rayle, L., Dai, D., Chan, N., Cervero, R., Shaheen, S.: Just a better taxi? A survey-based comparison of taxis, transit, and ridesourcing services in San Francisco. Transp. Policy 45, 168-178 (2016). https:// doi.org/10.1016/j.tranpol.2015.10.004

Schouten, A., Blumenberg, E., Taylor, B.: Rating the composition: Deconstructing the demand-side effects on transit use changes in California. Travel Behav Soc. 25, 18-26 (2021)

Taylor, B.D., Morris, E.: Public transportation objectives and rider demographics: are transit's priorities poor public policy? Transportation 42(2), 347-367 (2015). https://doi.org/10.1007/s11116-014-9547-0

Taylor, B.D., Miller, D., Iseki, H., Fink, C.: Nature and/or nurture? Analyzing the determinants of transit ridership across U.S. urbanized areas. Transp. Res. Part A Policy Pract. 43(1), 60-77 (2009)

The Economist: The used-car market sent American inflation soaring in June: Daily chart (13 July 2021)

U.S. Bureau of Labor Statistics: Consumer Price Index for All Urban Consumers: Used Cars and Trucks in U.S. City Average [CUSR0000SETA02], retrieved from FRED, Federal Reserve Bank of St. Louis. https://fred.stlouisfed.org/series/CUSR0000SETA02. 22 May 2020.

US Census. American Community Survey. 2016 1-Year Estimates. Factfinder.org (2016)

U.S. Federal Transit Administration. The National Transit Database (NTD). Federal Transit Administration. Retrieved from https://www.transit.dot.gov/ntd (2020)

Vinayak, P., Wafa, Z., Cheung, C., Tu, S., Komanduri, A., Overman, J., Goodwin, D.: Using smart farecard data to support transit network restructuring: findings from Los Angeles. Transp. Res. Rec. J. Transp. Res. Board 2673(6), 202-213 (2019)

Voulgaris, C.T., Taylor, B.D., Blumenberg, E., Brown, A., Ralph, K.: Synergistic neighborhood relationships with travel behavior: an analysis of travel in 30,000 US neighborhoods. J. Transp. Land Use 10(1), 437-461 (2017)

Publisher's Note Springer Nature remains neutral with regard to jurisdictional claims in published maps and institutional affiliations.

Michael Manville is Associate Professor Urban Planning at the UCLA Luskin School of Public Affairs.

Brian D. Taylor is a Professor of urban planning and public policy in the Luskin School of Public Affairs, and Director of the Institute of Transportation Studies at UCLA.

Evelyn Blumenberg is a Professor of Urban Planning and Director of the Lewis Center for Regional Policy Studies in the UCLA Luskin School of Public Affairs.

Andrew Schouten is an assistant professor in the College of Policy Science at Ritsumeikan University in Osaka, Japan. His research interests include travel behavior, and the relationship between residential location, personal mobility, and destination access. 